\title{
Adenosine Kinase Deficiency in the Brain Results in Maladaptive Synaptic Plasticity
}

\author{
OUrsula S. Sandau, ${ }^{1 \star}$ Mariana Colino-Oliveira, ${ }^{3,4 \star}$ Abbie Jones, ${ }^{1}$ Bounmy Saleumvong, ${ }^{1}$ Shayla Q. Coffman, ${ }^{1}$ \\ -Long Liu, ${ }^{2}$ @Catarina Miranda-Lourenço, ${ }^{3,4}$ Cátia Palminha, ${ }^{3,4}$ @Vânia L. Batalha, ${ }^{4}$ Yiming Xu, ${ }^{5}$ ○Yuqing Huo, \\ Maria J. Diógenes, ${ }^{3,4}$-Ana M. Sebastião, ${ }^{3,4 \dagger}$ and $\odot$ Detlev Boison ${ }^{1 \dagger}$ \\ ${ }^{1}$ R.S. Dow Neurobiology Laboratories and ${ }^{2}$ Department of Comparative Medicine, Legacy Research Institute, Portland, Oregon 97232, ${ }^{3}$ Institute of \\ Pharmacology and Neurosciences, Faculty of Medicine, Unit of Neurosciences, and ${ }^{4}$ Instituto de Medicina Molecular, Faculty of Medicine, University of \\ Lisbon, 1649-028 Lisbon, Portugal, and ${ }^{5}$ Vascular Biology Center, Department of Cellular Biology and Anatomy, Medical College of Georgia, Augusta \\ University, Augusta, Georgia 30912
}

Adenosine kinase (ADK) deficiency in human patients (OMIM:614300) disrupts the methionine cycle and triggers hypermethioninemia, hepatic encephalopathy, cognitive impairment, and seizures. To identify whether this neurological phenotype is intrinsically based on ADK deficiency in the brain or if it is secondary to liver dysfunction, we generated a mouse model with a brain-wide deletion of ADK by introducing a Nestin-Cre transgene into a line of conditional ADK deficient $\mathrm{Adk}^{\mathrm{f} / \mathrm{fl}}$ mice. These $\mathrm{Adk}^{\Delta \mathrm{brain}}$ mice developed a progressive stress-induced seizure phenotype associated with spontaneous convulsive seizures and profound deficits in hippocampus-dependent learning and memory. Pharmacological, biochemical, and electrophysiological studies suggest enhanced adenosine levels around synapses resulting in an enhanced adenosine $A_{1}$ receptor $\left(A_{1} R\right)$-dependent protective tone despite lower expression levels of the receptor. Theta-burst-induced LTP was enhanced in the mutants and this was dependent on adenosine $A_{2 A}$ receptor $\left(A_{2 A} R\right)$ and tropomyosinrelated kinase $B$ signaling, suggesting increased activation of these receptors in synaptic plasticity phenomena. Accordingly, reducing adenosine $\mathrm{A}_{2 \mathrm{~A}}$ receptor activity in $\mathrm{Adk}{ }^{\Delta \mathrm{brain}}$ mice restored normal associative learning and contextual memory and attenuated seizure risk. We conclude that ADK deficiency in the brain triggers neuronal adaptation processes that lead to dysregulated synaptic plasticity, cognitive deficits, and increased seizure risk. Therefore, ADK mutations have an intrinsic effect on brain physiology and may present a genetic risk factor for the development of seizures and learning impairments. Furthermore, our data show that blocking $\mathrm{A}_{2 \mathrm{~A}} \mathrm{R}$ activity therapeutically can attenuate neurological symptoms in ADK deficiency.

Key words: adenosine kinase; epilepsy; gene mutation; human genetic disorder; learning and memory; mouse model

Significance Statement

A novel human genetic condition (OMIM \#614300) that is based on mutations in the adenosine kinase (Adk) gene has been discovered recently. Affected patients develop hepatic encephalopathy, seizures, and severe cognitive impairment. To model and understand the neurological phenotype of the human mutation, we generated a new conditional knock-out mouse with a brainspecific deletion of $A d k\left(\mathrm{Adk}^{\Delta \text { brain }}\right)$. Similar to ADK-deficient patients, $A \mathrm{dk}^{\Delta \text { brain }}$ mice develop seizures and cognitive deficits. We identified increased basal synaptic transmission and enhanced adenosine $A_{2 A}$ receptor $\left(A_{2 A} R\right)$-dependent synaptic plasticity as the underlying mechanisms that govern these phenotypes. Our data show that neurological phenotypes in ADK-deficient patients are intrinsic to $\mathrm{ADK}$ deficiency in the brain and that blocking $\mathrm{A}_{2 \mathrm{~A}} \mathrm{R}$ activity therapeutically can attenuate neurological symptoms in ADK deficiency.

\section{Introduction}

Adenosine kinase $(\mathrm{ADK})$ is the key metabolic regulator of the purine ribonucleoside adenosine. In the adult brain, $\mathrm{ADK}$ is primarily expressed in astrocytes and determines the availability of

Received June 29, 2016; revised Oct. 3, 2016; accepted 0ct. 7, 2016.

Author contributions: U.S.S., M.J.D., A.M.S., and D.B. designed research; U.S.S., M.C.-O., A.J., B.S., S.Q.C., L.L., C.M.-L., C.P., V.L.B., and M.J.D. performed research; Y.X. and Y.H. contributed unpublished reagents/analytic tools; U.S.S., M.C.-O., and B.S. analyzed data; U.S.S., M.C.-O., M.J.D., A.M.S., and D.B. wrote the paper. adenosine in the synaptic cleft (Boison, 2013). Overexpression of $\mathrm{ADK}$ in the brain has been associated with the development of epilepsy and cognitive impairment (Li et al., 2008; Boison et al.,

This work was supported by the National Institutes of Health (Grants MH083973, NS088024, and HL09556) and the Fundação para a Ciência e Tecnologia (FTC Grant EXPL/BIM-MEC/0009/2013). M.C.-0. was funded by FCT Fellowship SFRH/BD/73276/2010.

The authors declare no competing financial interests.

*U.S.S. and M.C. -0 . contributed equally to this work.

${ }^{\dagger}$ A.M.S. and D.B. contributed equally to this work. 
2012), whereas therapeutic adenosine augmentation is considered a promising therapeutic strategy for the treatment of epilepsy (Boison et al., 2002a; Pritchard et al., 2010; Boison, 2013). Recently, the first human mutations in the Adk gene have been described (OMIM:614300) (Bjursell et al., 2011; Staufner et al., 2016). Consistent with a prominent role of ADK for the maintenance of transmethylation reactions in the liver (Boison et al., 2002b), six patients from three unrelated families displayed a hepatic phenotype composed of disruption of the transmethylation cycle, dysregulation of hepatic metabolites, and hepatic encephalopathy (Bjursell et al., 2011). Affected individuals presented with global psychomotor delay and convulsive seizures commencing between the first and third year of life (Bjursell et al., 2011). Subsequently, 11 additional patients with ADK deficiency from eight families were identified; microvesicular hepatic steatosis and global developmental delay were prominent and most patients developed seizures and cognitive impairment (Staufner et al., 2016). Given the neuroprotective and anticonvulsive properties of adenosine, the neurological phenotype of patients with inborn $\mathrm{ADK}$ deficiency is somewhat surprising.

In the brain, adenosine modulates neurotransmission primarily through binding to its two high-affinity G-proteincoupled receptors: the inhibitory adenosine $A_{1}$ receptor $\left(A_{1} R\right)$ and the stimulatory $A_{2 A}$ receptor $\left(A_{2 A} R\right)$ (Chen et al., 2013). The predominant action of adenosine is the inhibition of synaptic transmission via $\mathrm{A}_{1} \mathrm{R}$-mediated signaling and, in rodent models of epilepsy, this signaling pathway is impaired, accounting for increased excitability and susceptibility to seizures (Rebola et al., 2003). Despite lower expression levels of the $A_{2 A} R$ in the hippocampus, activation of $\mathrm{A}_{2 \mathrm{~A}} \mathrm{Rs}$ influences the release and uptake of neurotransmitters and also facilitates excitatory tropomyosinrelated kinase B (TrkB)-mediated BDNF actions (Diógenes et al., 2004; Fontinha et al., 2008). To determine whether the neurological phenotype in ADK-deficient patients is secondary to hepatic encephalopathy or if it is intrinsic to ADK deficiency in the brain, we generated mice with a brain-wide deletion of ADK. This was achieved by breeding conditional $A d k-f l o x\left(\mathrm{Adk}^{\mathrm{fl} / \mathrm{fl}}\right)$ with NestinCre mice (Burns et al., 2007) to yield Nestin-Cre ${ }^{+/-}: \mathrm{Adk}^{\mathrm{fl} / \mathrm{fl}}$ $\left(\mathrm{Adk}^{\Delta \text { brain }}\right)$ mice. These mutants completely lacked ADK in the brain and developed progressive stress-induced seizures and deficits in learning and memory. We identified a novel mechanism in which the complete lack of ADK in the brain drives neuronal adaptation processes that lead to enhanced basal synaptic transmission.

\section{Materials and Methods}

Transgenic mice. The Adk gene targeting vector to produce global ADK knock-out mice ( $A d k^{\text {tmlbois}}$ ) has been fully described previously (Boison et al., 2002b; Fedele et al., 2004). Briefly, the targeting construct was reengineered and exon 7 of the Adk gene was flanked with loxP sites. Through homologous recombination in embryonic stem cells, an $A d k^{\mathrm{fl} /}-$ allele was created, which was used to generate a line of $A d k^{\mathrm{f} / \mathrm{fl}}$ mice. $A d k^{\mathrm{f} / \mathrm{fl}}$ mice were crossbred with constitutive Nestin-Cre mice (Tronche et al., 1999) (The Jackson Laboratory, RRID: IMSR_JAX:003771) to generate Nestin-Cre ${ }^{+/-}$: $\mathrm{Adk}^{\mathrm{fl} / \mathrm{fl}}$ mice. Nestin-Cre mice express the Cre driver as early as embryonic day 11, resulting in Cre activation in neuronal and astroglial lineages (Tronche et al., 1999), a strategy chosen to achieve a brain-wide deletion of $\mathrm{ADK}$, which is predominantly expressed in astrocytes of the adult brain (Studer et al., 2006). To exclude any Cre related experimental confounds,

Correspondence should be addressed to Detlev Boison, RS Dow Neurobiology Laboratories, Legacy Research Institute, 1225 NE $2^{\text {nd }}$ Ave, Portland, OR 97232. E-mail: dboison@downeurobiology.org.

DOI:10.1523/JNEUROSCI.2146-16.2016

Copyright $\odot 2016$ the authors $\quad 0270-6474 / 16 / 3612118-12 \$ 15.00 / 0$ additional Nestin-Cre ${ }^{+/-}$mice without Adk-flox alleles were included in our in vivo studies. Nestin-Cre ${ }^{+/-}: \mathrm{Adk}^{\mathrm{fl} / \mathrm{fl}}: \mathrm{A}_{1} \mathrm{R}^{-1-}$ mice and Nestin$\mathrm{Cre}^{+/-}: \mathrm{Adk}^{\mathrm{f} / \mathrm{fl}}: \mathrm{A}_{2 \mathrm{~A}} \mathrm{R}^{-/-}$were generated by breeding Nestin-Cre ${ }^{+/-}$: $\mathrm{Adk}^{\mathrm{fl} / \mathrm{fl}}$ mice with global $\mathrm{A}_{1} \mathrm{R}^{-/-}$(Johansson et al., 2001) or $\mathrm{A}_{2 \mathrm{~A}} \mathrm{R}^{-/-}$mice (Day et al., 2003), respectively. Offspring were then backcrossed until Nestin-Cre ${ }^{+/-}: \mathrm{Adk}^{\mathrm{f} / \mathrm{fl}}: \mathrm{A}_{1} \mathrm{R}^{-/-}$and Nestin-Cre ${ }^{+/-}: \mathrm{Adk}^{\mathrm{fl} / \mathrm{fl}}: \mathrm{A}_{2 \mathrm{~A}} \mathrm{R}^{-/-}$mice were generated. Breeding of the experimental animals followed either a Nestin-Cre ${ }^{+-}:$Adk $^{\mathrm{fl} / \mathrm{fl}}$ mice $\times$ Nestin-Cre ${ }^{-/-}: \mathrm{Adk}^{\mathrm{fl} / \mathrm{fl}}$, Nestin-Cre ${ }^{+/-}: \mathrm{Adk}^{\mathrm{fl} / \mathrm{fl}}$ : $\mathrm{A}_{1} \mathrm{R}^{-/-} \times$Nestin-Cre ${ }^{-/-}: \mathrm{Adk}^{\mathrm{fl} / \mathrm{fl}}: \mathrm{A}_{1} \mathrm{R}^{-/-}$or Nestin-Cre ${ }^{+/-}: \mathrm{Adk}^{\mathrm{fl} / \mathrm{fl} \text { : }}$ $\mathrm{A}_{2 \mathrm{~A}} \mathrm{R}^{-/-} \times$Nestin-Cre ${ }^{-/-}: \mathrm{Adk}^{\mathrm{fl} / \mathrm{fl}}: \mathrm{A}_{2 \mathrm{~A}} \mathrm{R}^{-/-}$mating protocol, which generated ADK-deficient and normal mice in a 1:1 ratio as littermates. All mice were generated and propagated on an identical C57BL/6 background and were genotyped at weaning by PCR. If not indicated otherwise, male subjects were used. All animals were social housed under standardized conditions of light, temperature, humidity, and environmental enrichment and had ad libitum access to food and water. Experimental animals used for this study were taken between 2 and 8 months of age. In vivo studies were conducted in an Association for Assessment and Accreditation of Laboratory Animal Care International (AAALAC)-accredited facility in accordance with protocols approved by the Legacy Institutional Animal Care and Use Committee. Ex vivo assays were performed according to procedures approved by the Portuguese authorities (DL 113/2013) and European Community Guidelines for Animal Care (European Communities Council Directive 2010/63/EU).

PCR. Tissue from mice was obtained by tail clipping or from specific organs. Genomic DNA was prepared following standard procedures. For genotyping, Cre DNA sequence amplification with primers 5 '-GGACAT GTTCAGGGATCGCCAGGCG-3' and 5'-GGACATGTTCAGGGAT CGCCAGGCG-3' was performed. For genomic Adk, the primer sequences were as follows: $5^{\prime}$-CCTCTATGAGTTGAGATCCTGTCTCC-3' and 5'ATTTATTAACTTTACATAGATTCAGACAG- $3^{\prime}$. The Cre and Adk PCRs were paired with a genomic internal positive control using primers oIMR7338 (5'-CTAGGCCACAGAATTGAAAGATCT-3') and oIMR7339 (5'-GTAGGTGGAAATTCTAGCATCATCC-3') (The Jackson Laboratory). PCR products were loaded in a $2 \%$ agarose gel dyed with ethidium bromide for band visualization. For qRT-PCR, cortical samples were homogenization in QiAzol Lysis Reagent (Qiagen) and RNA was extracted, using the RNeasy Lipid Tissue Mini Kit (Qiagen). For first-strand cDNA synthesis, $1.5 \mu \mathrm{g}$ of total RNA was applied in each reaction according to the manufacturer's protocol (SuperScript III Reverse Transcriptase; Invitrogen Life Technologies). For cDNA amplification, $2 \mu \mathrm{l}$ of 1:10 diluted cDNA was added to $12.5 \mu$ l of $2 \times$ Power SYBR Green PCR Master Mix (Life Technologies) and $1 \mu \mathrm{l}$ of each primer $(5 \mu \mathrm{M})$ in a reaction volume of $25 \mu \mathrm{l}$. All reactions were performed in duplicate. The qRT-PCRs were performed on an RT-PCR Rotor Gene 6000 device (Corbett Life Science). Melting curves were analyzed to confirm primer specificity and the comparative $C_{\mathrm{t}}$ (threshold cycle) method was for quantification according to the following formula: $C_{\mathrm{t}}=C_{\mathrm{t}}($ target gene $)-C_{\mathrm{t}}($ reference gene $)$. The genes used to normalize the expression of the target sequences were PPIA peptidylprolyl isomerase A (cyclophilin A, CypA) and ribosomal protein L13A (RpL13A). Primers used were as follows: $5^{\prime}$-TATCTGCACTGCCAAGACTGAGTG-3' and 5' CTTCTTGCTGGTCTTGCCATTCC-3' for CypA; 5'-GGATCCCTCCA CCCTATGACA-3' and $5^{\prime}$-CTGGTACTTCCACCCGACCTC-3' for RpL13A; and 5' -TCGGCTGGCTACCACCCCTTG- $3^{\prime}$ and 5' - CCAGCAC CCAAGGTCACACCAAAGC-3' for $\mathrm{A}_{1} \mathrm{R}$

Analysis and quantification of induced seizures. Stress-induced seizures were evoked in Adk ${ }^{\Delta \text { brain }}$ mice by placing animals into a novel environment and characterized by tonic-clonic seizure activity followed by rearing and falling. Seizures were scored for occurrence and duration. Please see Movie 1 for a representative stress-induced seizure. Adk ${ }^{\Delta \text { brain }}$ mice used for the quantification of stress-induced seizures were naive to any additional treatments. During this period, the mice were exclusively handled by the same investigators. The probability of an evoked seizure was calculated for each mouse as the number of evoked seizures relative to the total number of trials within a month and then reported as the group average. Additional animals were equipped with a bipolar electrode surgically implanted into the hippocampus (AP: $-1.94 ; \mathrm{ML}:-1.25, \mathrm{DV}:-1.5$, relative to bregma) with a surface cortical monopolar screw electrode and cerebellum reference screw electrode while under general anesthesia $(2 \%$ isofluo- 


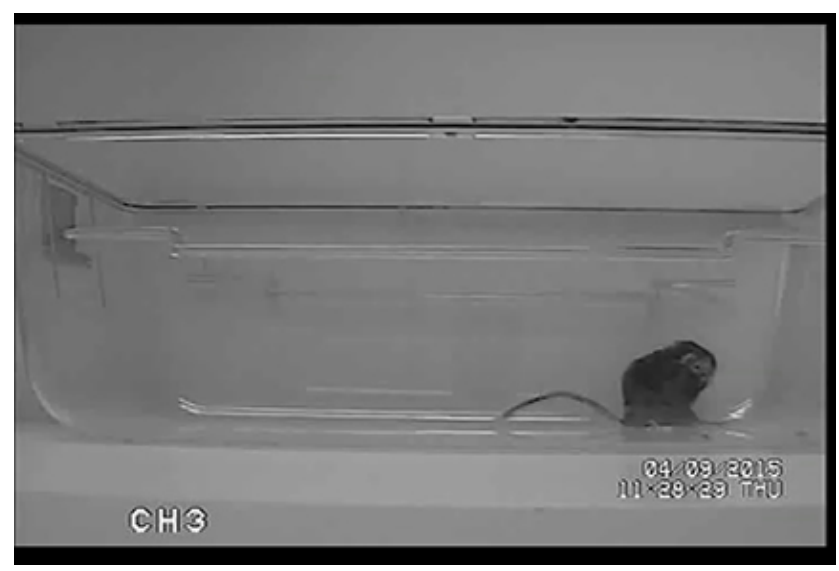

Movie 1. Stress-induced tonic convulsive seizure in an $\mathrm{Adk}^{\Delta \text { brain }}$ mouse. The movie is of a representative stress-induced seizure that is triggered by placing the mouse in a novel environment. The seizure is characterized by multiple bouts of tonic-clonic, rearing, and falling activity.

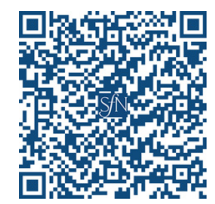

rane, $100 \% \mathrm{O}_{2}$ ). Video EEG recordings occurred at least 1 week after surgery. Mice were tethered for the EEG recordings. Electrical brain activity was amplified and digitized using a Nervus EEG recording system. Pharmacologically induced seizures were evoked by intraperitoneal injection of the $A_{1} R$ antagonist DPCPX (up to $3.5 \mathrm{mg} / \mathrm{kg}$; Sigma-Aldrich). For the DPCPX threshold test, mice received $0.5 \mathrm{mg} / \mathrm{kg}$ DPCPX intraperitoneally every 10 min until a convulsive tonic-clonic seizure was induced up to a maximum cumulative dose of $3.5 \mathrm{mg} / \mathrm{kg}$ DPCPX. For the high-dose DPCPX experiment, a single dose of $3.0 \mathrm{mg} / \mathrm{kg}$ intraperitoneal DPCPX was administered and the latency to tonic-clonic seizure and mortality were indexed. The $\mathrm{A}_{2 \mathrm{~A}} \mathrm{R}$ antagonist SCH58261 or the TrkB antagonist Ana-12 (0.5 mg/kg, 5\% DMSO, i.p.; Sigma-Aldrich) were administered either $30 \mathrm{~min}$ or $4 \mathrm{~h}$ before DPCPX, respectively.

Assessment of baseline EEG activity and spontaneous seizures. Spontaneous seizures were assessed by video EEG in 6-month-old Adk ${ }^{\Delta \text { brain }}$ mice $(n=6)$ and nestin-Cre ${ }^{+/-}$mice $(n=4)$ for $7 \mathrm{~d}$. Additional baseline EEG recordings were conducted in all three lines of control mice (wild-type, nestin-Cre ${ }^{+/-}$, and $\mathrm{Adk}^{\mathrm{fl} / \mathrm{fl}}$ ) plus $\mathrm{Adk}^{\Delta \text { brain }}$ mice for $3 \mathrm{~d}(n=5$ /genotype). Animals were equipped with EEG recording electrodes as described above. Electrical brain activity was monitored using a Nervus EEG recording system connected with a Nervus Magnus 32/8 Amplifier and filtered (high-pass filter $50 \mathrm{~Hz}$ cutoff, low-pass $1 \mathrm{~Hz}$ ). The digital EEG signal was recorded, stored, and visualized using a NicoletOne-System (Viasys Healthcare). Videos were acquired with Lorex cameras and a DVR. EEG recordings were scored in their entirety for seizure activity. EEG seizure activity was defined as high-amplitude rhythmic discharges that clearly represented a new pattern of tracing lasting for $>5 \mathrm{~s}$. EEG seizures were confirmed to have a tonic-clonic behavioral correlated with the corresponding time-matched video.

Behavioral assessment of mice. Conditioned learning and contextual memory were conducted using a classic fear-conditioning paradigm (Wehner and Radcliffe, 2004) with a Med Associates Fear Conditioning chamber and Video Freeze software (RRID: SCR_014574). Testing consisted of a 2 d paradigm. Day 1 was conditioned learning, including a baseline activity trial ( $3 \mathrm{~min}$ in the arena) and then 4 trials of conditioning stimuli (CS, $90 \mathrm{~dB}$ white noise, $30 \mathrm{~s}$ ) immediately followed by aversive foot shock $(0.3 \mathrm{~mA}, 1 \mathrm{~s})$ with an intertrial interval (ITI) of $3 \mathrm{~min}$. Freezing was measured during the ITI. Day 2 was contextual memory testing, in which mice were returned to the same arena and freezing was measured during 8 consecutive $1 \mathrm{~min}$ bins. Data are represented as the group average for percentage time freezing. The fear-conditioning paradigm was performed in animals that did not respond to seizure induction or in animals that were in their refractory period $2 \mathrm{~h}$ after a preceding seizure. There were no significant differences between the two groups of animals (associative learning, $p=0.58$; contextual memory, $p=0.79$ ). Animals that had a stress-induced seizure during the fear-conditioning paradigm were excluded from the analysis.

Brain dissection for electrophysiology. All mice were quickly anesthetized with isofluorane before decapitation to minimize stress. No signs of seizures were detected in $\mathrm{Adk}^{\Delta \text { brain }}$ mice at the time of euthanasia. The brain was quickly removed and hippocampi and cortices were dissected in ice-cold aCSF containing the following (in $\mathrm{mm}$ ): $\mathrm{NaCl} \mathrm{124,} \mathrm{KCl} 3$, $\mathrm{NaH}_{2} \mathrm{PO}_{4}$ 1.25, $\mathrm{NaHCO}_{3} 26, \mathrm{MgSO}_{4} 1, \mathrm{CaCl}_{2}$ 2, and glucose 10, $\mathrm{pH}$ 7.4. While the other brain areas were frozen at $-80^{\circ} \mathrm{C}$ until further use, one of the hippocampi was sliced $(400 \mu \mathrm{m})$ perpendicularly to its longitudinal axis using a McIlwain tissue chopper. Slices were then immediately transferred to a resting chamber filled with the same solution at room temperature and allowed to recover for at least $1 \mathrm{~h}$ before use in extracellular recordings. For each of the experimental paradigms described below, we used at least one slice per mouse; all $n$ values stated are based on the group size of mice with their respective genotype.

Extracellular recordings. Slices were transferred to a recording chamber and submerged with oxygenated aCSF solution at $32^{\circ} \mathrm{C}$, continuously superfused at a flow rate of $3 \mathrm{ml} / \mathrm{min}$. When indicated, drugs were added to the superfused solution. Recordings were obtained with an Axoclamp 2B amplifier and digitized (Molecular Devices). Evoked field EPSPs (fEPSPs) were recorded extracellularly through a microelectrode filled with $4 \mathrm{M} \mathrm{NaCl}$ (2-6 $\mathrm{M} \Omega$ resistance) placed in the stratum radiatum of the CA1 area. A concentric electrode was placed on the Schaffer collateralcommissural fibers in stratum radiatum near the CA3-CA1 border and used to deliver the stimulation (rectangular $0.1 \mathrm{~ms}$ pulses once every $15 \mathrm{~s}$ ). Individual responses were monitored and averages of eight (basal synaptic transmission) or six (LTP induction and input-output curve) consecutive responses were continuously stored on a personal computer with the WinLTP software (RRID: SCR_008590).

Drugs used for electrophysiological studies. DPCPX (1,3-dipropyl-8cyclopentylxanthine, $\mathrm{A}_{1} \mathrm{R}$ antagonist) was obtained from Ascent Scientific (Bristol, UK). CGS21680 (2-[p-(2-carboxyethyl)phenethylamino]-5-Nethyl-carboxamido adenosine, $\mathrm{A}_{2 \mathrm{~A}} \mathrm{R}$ agonist) was purchased from Sigma (St Louis, MO). K252a (Tyrosine kinase inhibitor) and SCH58261 (2-(2Furanyl)-7-(2-phenylethyl)-7H-pyrazolo[4,3-e][1,2,4] triazolo[1,5-c]pyrimidin-5-amine, $\mathrm{A}_{2 \mathrm{~A}} \mathrm{R}$ antagonist were purchased from Tocris Bioscience Cookson (Ballwin, MO). DPCPX, SCH58261 and CGS21680 were prepared in a $5 \mathrm{~mm}$ and $\mathrm{K} 252 \mathrm{a}$ in a $1 \mathrm{~mm}$ stock solution, all in DMSO. The percentage of DMSO in each experiment did not exceed $0.001 \%$.

Basal synaptic transmission. The intensity of stimulus $(80-200 \mu \mathrm{A})$ was initially adjusted to obtain a submaximal fEPSP slope (near $0.5 \mathrm{mV} / \mathrm{ms}$ ) with a minimum population spike contamination. Alteration in synaptic transmission induced by drugs was evaluated as the percentage change in the average slope of the fEPSP in the presence of the drug in relation to the average slope of the fEPSP measured during the 10 min that preceded its addition.

Input-output curve. Once obtaining a stable baseline for at least 15 min, the stimulus delivered to the slice was decreased to $60 \mu \mathrm{A}$, with fEPSPs disappearance. The stimulus was delivered to the slice in successively increased steps of $20 \mu \mathrm{A}$ until a supramaximal stimulation of 340 $\mu \mathrm{A}$. For each stimulation condition, data from three consecutive average fEPSP were stored. The Input-Output curve was plotted as the relationship of fEPSP slope (ms) vs stimulus intensity ( $\mu \mathrm{A})$.

LTP induction. After obtaining a $14 \mathrm{~min}$ stable baseline of fEPSP slope by $0.5 \mathrm{~ms}$, LTP was induced by a theta-burst protocol as described previously (Diógenes et al., 2011). This protocol consisted of three trains of three stimuli delivered at $100 \mathrm{~Hz}$, each separated by $200 \mathrm{~ms}$; the intensity of the stimulus was kept constant before, during, and after the induction protocol. LTP was quantified as the percentage change in the average slope of fEPSP taken from 52-60 min after LTP induction in relation to the average slope of the fEPSP measured during the baseline period (10 min before LTP induction). While assessing LTP in the presence of drugs, LTP was only induced no less than 30 min after starting the drug perfusion and only after fEPSP slope values had stabilized.

Western blot and saturation binding assays. Dissected brain samples were homogenized in chilled $0.32 \mathrm{M}$ sucrose solution with $50 \mathrm{~mm}$ Tris, $\mathrm{pH}$ 7.6, plus protease inhibitors (Hoffmann LaRoche) and then centrifuged. 


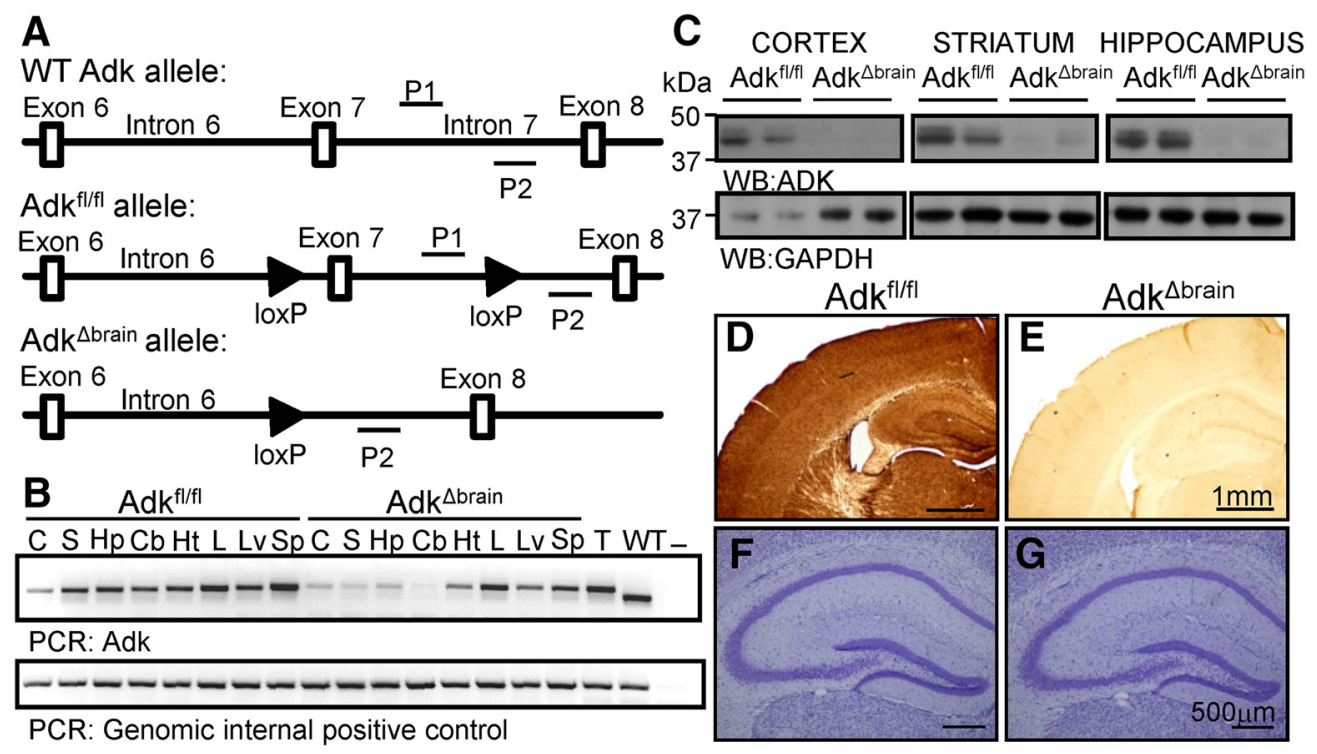

Figure 1. Brain-specific deletion of ADK in Adk ${ }^{\Delta \text { brain }}$ mice. $A$, Transgenic strategy: exon 7 of the Adk allele is flanked with loxP sites in Adk ${ }^{f / / f l}$ mice. $B$, Adk PCR on genomic DNA extracts from the cortex (C), striatum (S), hippocampus (Hp), cerebellum (Cb), heart (Ht), lung (L), liver (Lv), and spleen (Sp) from Adk ${ }^{\mathrm{flffl}}$ and Adk ${ }^{\Delta b^{2} \text { rain }}$ mice. Tail DNA from an Adk ${ }^{\mathrm{fl} / \mathrm{fl}}(\mathrm{T})$ and wild-type mouse (WT) were included as positive controls. Water (-) was included as a no-template control. Adk forward and reverse primer (P1 and P2) sites are depicted in A. C, ADK ( $40 \mathrm{kDa}$ ) Western blots on cortical, striatal, and hippocampal protein extracts from Adk ${ }^{\mathrm{flfl}}$ and $\mathrm{Adk}{ }^{\mathrm{\Delta brain}}$ mice; $n=2 /$ genotype are used as representatives. ADK Western blots were reprobed with GAPDH (37 kDa) as a loading control.

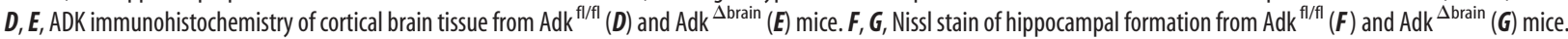

Protein was quantified using a Bio-Rad Protein assay kit. Next, 25-200 $\mu \mathrm{g}$ of aqueous protein extracts from tissue were loaded and separated on $10 \%$ SDS-PAGE gels and transferred onto PVDF membranes (Millipore). The blots were probed overnight at $4^{\circ} \mathrm{C}$ with primary antibody anti-ADK (1:4000, RRID pending; Gouder et al., 2004) and anti-GAPDH (1:500, catalog \#sc-47724 RRID:AB_627678; Santa Cruz Biotechnology) as internal standards. The specificity of the ADK antibody has been validated previously in knock-out samples (Fedele et al., 2004; Gouder et al., 2004). The membranes were incubated with secondary antibody anti-mouse (1:2000, catalog \#A-10677 RRID:AB_2534060; Thermo Fisher Scientific) or anti-rabbit (1:10,000, catalog \#G-21234 RRID: AB_2536530; Thermo Fisher Scientific) conjugated with horseradish peroxidase for $1 \mathrm{~h}$ at room temperature. Chemoluminescence detection was performed with an ECL-PLUS Western blot detection reagent (GE Healthcare) using X-ray films (Fujifilm). The saturation binding experiments were adapted from a previous protocol (Batalha et al., 2013). $\left[{ }^{3} \mathrm{H}\right] \mathrm{DPCPX}$ (radiolabeled $\mathrm{A}_{1} \mathrm{R}$ antagonist, specific activity $120 \mathrm{Ci} /$ mmol) was from GE Healthcare. [ $\left.{ }^{3} \mathrm{H}\right] \mathrm{DPCPX}(0-42 \mathrm{nM})$ (specific activity $120 \mathrm{Ci} / \mathrm{mmol}$ ) was incubated for $2 \mathrm{~h}$ at room temperature with $39-77$ $\mu \mathrm{g}$ of protein homogenate and $4 \mathrm{U} / \mathrm{ml}$ adenosine deaminase in a solution containing $50 \mathrm{~mm}$ Tris, $2 \mathrm{~mm} \mathrm{MgCl}_{2} \cdot 6 \mathrm{H}_{2} \mathrm{O}$, pH 7.4, with a final volume of $300 \mu$ l. Each reaction was performed in duplicate. Nonspecific binding was measured in the presence of $2 \mu \mathrm{M} \mathrm{XAC}$ and normalized for protein concentration. Binding reactions were stopped by vacuum filtration with a Skatron semiautomatic cell harvester using chilled incubation solution. Filtermats $1.5 \mu \mathrm{m}$ (Molecular Devices) were used and placed in scintillation vials to which $3 \mathrm{ml}$ of scintillation mixture (OptiPhase HiSafe 2; PerkinElmer) was added. Radioactivity bound to the filters was determined after $12 \mathrm{~h}$ with an efficiency of $55-60 \%$ for $2 \mathrm{~min}$.

Immunohistochemistry. ADK and Nissl staining was performed on $4 \%$ paraformaldehyde-fixed coronal brain sections $(40 \mu \mathrm{m})$ using standard protocols (Studer et al., 2006). High-resolution digital images were acquired using equivalent settings with a Leica DM1000 bright-field microscope equipped with a DCF295 camera and LAS AF Image Acquisition Software (RRID: SCR_013673; Leica Microsystems).

Statistical analysis. Analyses were conducted with Prism 7 software (RRID: SCR_002798; GraphPad) and statistical significance was assumed at $p<0.05$. Repeated-measures two-way ANOVA followed by Tukey's, Dunnett's, or Sidak's multiple-comparison tests; two-way ANOVA followed by Tukey's multiple-comparison test; nonlinear re- gression fit test; or two-tailed unpaired $t$ tests were used as appropriate. The two-tailed Mann-Whitney test or Kruskal-Wallis test followed by Dunn's multiple-comparisons test were used for nonparametric analysis where appropriate. Kaplan-Meier survival curves were analyzed by logrank (Mantel-Cox) tests.

\section{Results}

Conditional deletion of the $A d k$ gene causes brain-wide ADK deficiency

To provide mechanistic evidence that ADK deficiency in the brain could be a primary cause for neurological symptoms in ADK-deficient patients, we engineered a novel line of mice with brain-wide disruption of ADK. First, our Adk gene-targeting construct (Boison et al., 2002b) was modified to flank exon 7 of the $A d k$ gene with loxP sites (Fig. $1 A$ ). This construct was used to generate $A d k^{\mathrm{fl} / \mathrm{fl}}$ mice, which were then crossed with Nestin-Cre mice (Burns et al., 2007) to generate mutant Adk ${ }^{\Delta \text { brain }}$ mice and normal $\mathrm{Adk}^{\mathrm{fl} / \mathrm{fl}}$ littermates. PCR analysis validated selective deletion of the $A d k$ allele in representative brain regions of $A d k^{\Delta b r a i n}$ mice, whereas the intact $A d k$ gene was maintained in peripheral organs of $A \mathrm{dk}^{\Delta \text { brain }}$ mice and in all tissues from $\mathrm{Adk}^{\mathrm{fl} / \mathrm{fl}}$ mice (Fig. $1 B)$. Consistent with intact $A d k$ gene expression in the liver of $A d k^{\Delta b r a i n}$ mice, the gross liver morphology was normal and did not show any signs of lipid accumulation with oil-red-O staining (data not shown). In addition, $\mathrm{Adk}^{\Delta \text { brain }}$ mice did not show any appreciable differences in reproduction and life span. Western blot analysis (Fig. 1C) and ADK immunohistochemistry (Fig. $1 D, E)$ corroborated a complete lack of ADK expression throughout the brains of the $A \mathrm{dk}^{\Delta \mathrm{brain}}$ mice without affecting gross morphology (Fig. 1F, G).

\section{Brain-wide disruption of ADK results in increased} susceptibility to seizure induction

$\mathrm{Adk}^{\Delta \mathrm{brain}}$ mice initially developed normally. However, from 2 months on, the animals developed increased susceptibility to stress-induced seizures that were reliably induced by placing animals into a novel environment (i.e., a clean observation 


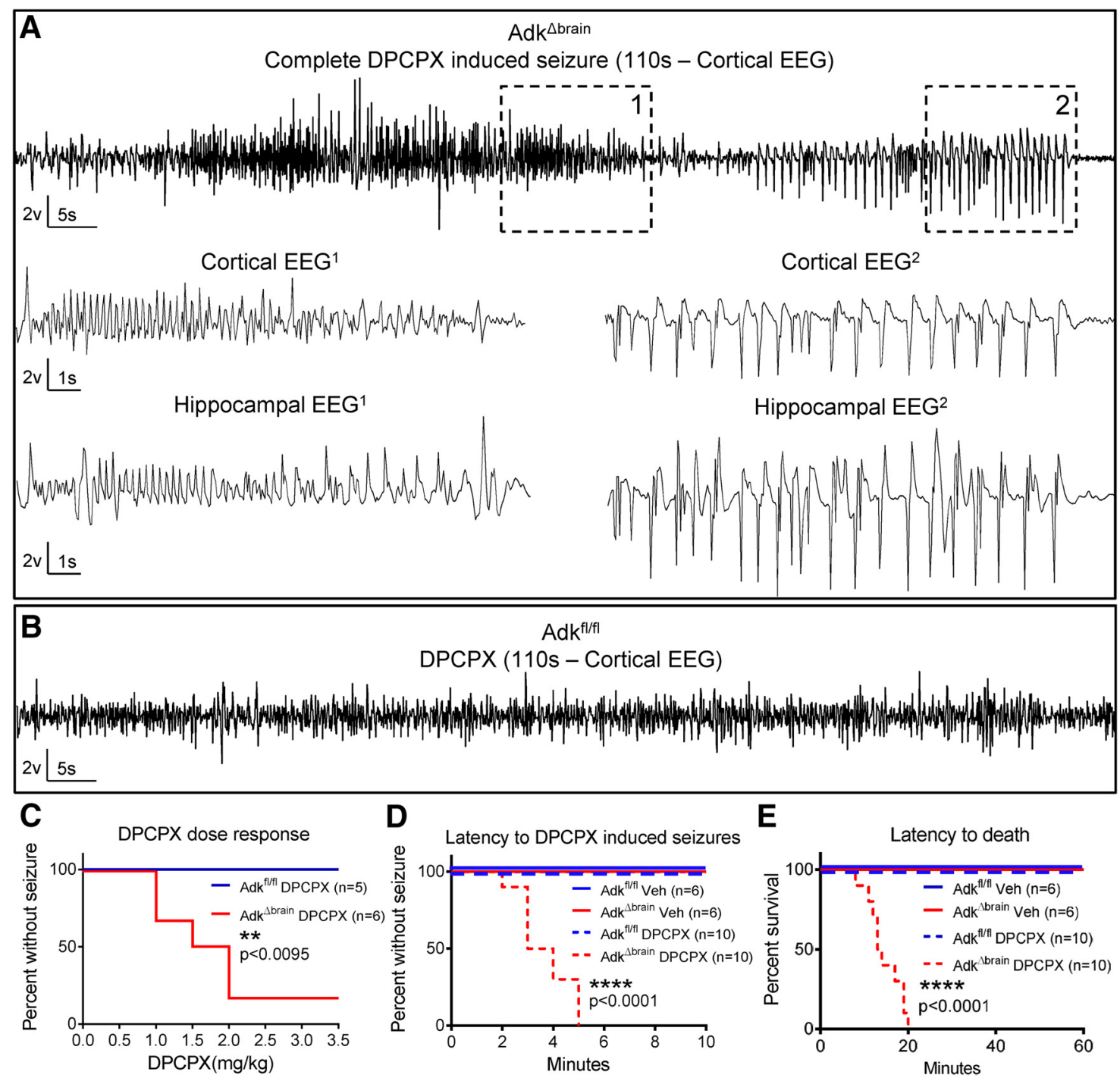

Figure 2. Loss of brain ADK results in increased susceptibility to seizure induction. $\boldsymbol{A}$, Representative cortical EEG trace that includes a complete DPCPX-induced seizure (110 s) in an $A d k^{\Delta b r a i n}$ mouse that received a total cumulative dose of $2.0 \mathrm{mg} / \mathrm{kg}$ DPCPX intraperitoneally. High-resolution portions (15 s) of the DPCPX-induced seizure are depicted in cortical/ hippocampal EEG ${ }^{1}$ and EEG ${ }^{2}$. These EEG traces correspond to boxes demarcated with 1 and 2 in upper cortical trace. See Movie 2 for a matching behavioral seizure. $B, D P C P X$ does not trigger seizures in Adk ${ }^{\mathrm{fl} / \mathrm{fl}}$ control mice. Shown is a representative section of a cortical EEG trace (110 s) recorded after a cumulative dose of $3.5 \mathrm{mg} / \mathrm{kg} D P C P X$ intraperitoneally. $C, D P C P X$ dose response $(0.5 \mathrm{mg} / \mathrm{kg}$, i.p., every $10 \mathrm{~min})$ in Adk ${ }^{\Delta \text { brain }}$ mice $(n=6)$ and Adk ${ }^{\text {fl/fl }}$ mice $(n=5)$. D, E, DPCPX $\left(3 \mathrm{mg} / \mathrm{kg}\right.$, i.p.) administered to Adk ${ }^{\Delta \text { brain }}$ mice $(n=10)$ causes status epilepticus $\left(\boldsymbol{D}^{* * * *} p<0.0001\right)$ and increased mortality $\left(\boldsymbol{E}^{*}{ }^{* * *} p<0.0001\right)$ compared with DPCPX-treated Adk ${ }^{\mathrm{fl} / \mathrm{fl}}$ mice $(n=10)$, vehicle-treated Adk ${ }^{\mathrm{fl} / f l}$ mice $(n=6)$, and vehicle-treated Adk ${ }^{\Delta \text { brain }}$ mice $(n=6)$. Statistical analysis: log-rank (Mantel-Cox) test.

area) and characterized by tonic-clonic convulsions (see a representative seizure in Movie 1). These evoked seizures lasted an average of $2.48 \pm 0.18 \mathrm{~min}(n=7)$ and a marked progression of this seizure phenotype with age was found. By 3 months of age, $44 \%$ of all Adk ${ }^{\Delta \text { brain }}$ mice reacted with a seizure upon being placed into a novel environment; by 4 months of age, the incidence of seizure response within the same Adk ${ }^{\Delta \text { brain }}$ population was at $89 \%$ and continued to $100 \%$ by 6 months of age. Likewise, the probability of an evoked seizure response in the $\mathrm{Adk}^{\Delta \mathrm{brain}}$ mice rose from $7.4 \%$ at 2 months of age to $77 \%$ at 6 months. Because pharmacological blockade of ADK is a very effective therapeutic strategy to suppress seizures in clinically relevant animal models of epilepsy (Gouder et al., 2004; McGaraughty et al., 2005; Boison, 2016a, 2016b), the emergence of the stress-induced seizure phenotype in $A k^{\Delta b r a i n}$ mice was an unexpected finding. To identify the underlying mechanisms of seizure induction in $\mathrm{Adk}^{\Delta \text { brain }}$ mice, we next sought to replicate seizure induction in $\mathrm{Adk}^{\Delta \text { brain }}$ mice with well controlled pharmacological tools.

Because adenosine $\mathrm{A}_{1}$ Rs link to potent anticonvulsant mechanisms (Gouder et al., 2003; Fedele et al., 2006; Kochanek et al., 2006; Gomes et al., 2011; Chen et al., 2013), $A_{1} R$ function in $A d k^{\Delta b r a i n}$ mice was tested. Injection of the $A_{1} R$ antagonist DPCPX (1.0 - $2.0 \mathrm{mg} / \mathrm{kg}$, i.p.) at doses that do not trigger seizures in control mice (Masino et al., 2011; Fig. 2B) triggered a convulsive seizure in 5 of $6 \mathrm{Adk}^{\Delta \text { brain }}$ mice (Fig. $2 A, C$, Movie 2). Furthermore, $\mathrm{Adk}^{\mathrm{fl} / \mathrm{fl}}$ control mice $(n=5)$ were unaffected by higher doses up $3.5 \mathrm{mg} / \mathrm{kg}$ (Fig. $2 \mathrm{~B}, \mathrm{C}$ ). Therefore, pharmacological blockade of the $A_{1} R$ could be used to induce seizures reliably in lieu of stress in Adk ${ }^{\Delta \text { brain }}$ mice (Mantel-Cox test, $\chi_{(1)}^{2}=6.73$, ${ }^{* *} p=0.0095$; Fig. $2 C$ ). Next, it was determined that a single injection with a higher dose of the $A_{1} R$ antagonist DPCPX (3 mg/kg i.p.) consistently triggered lethal status epilepticus in 


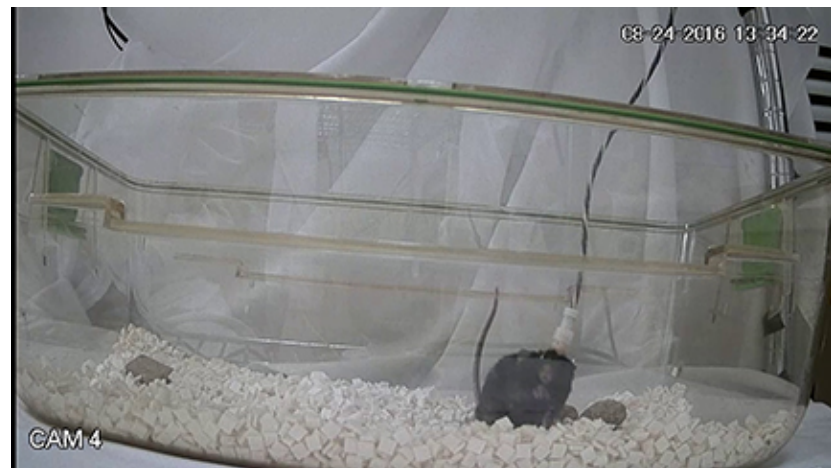

Movie 2. DPCPX-induced tonic convulsive seizure in an Adk ${ }^{\Delta \text { brain }}$ mouse. The movie is of a representative DPCPX-induced seizure that was triggered with a final cumulative dose of $2.0 \mathrm{mg} / \mathrm{kg}$ DPCPX. The seizure is the behavioral correlate of the cortical and hippocampal EEG traces shown in Figure $2 A$. The seizure is characterized by bouts of tonic clonic, rearing, falling, running, and jumping activity.

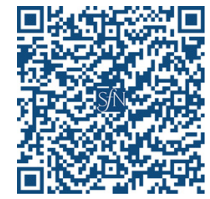

$\mathrm{Adk}^{\Delta \text { brain }}$ mice (10 of 10 mice), but not in $\mathrm{Adk}^{\mathrm{f} / / \mathrm{fl}}$ mice ( 0 of 10 mice; Fig. $2 D, E)$. Together, these data demonstrate that, despite increased susceptibility for inducible seizures in $\mathrm{Adk}^{\Delta \mathrm{brain}}$ mice, the $A_{1} R$ maintains an inhibitory and protective function.

\section{Brain-wide disruption of ADK results in spontaneous seizures}

To rule out that the Nestin-Cre expression or the Adk flox mutation affects the EEG baseline, 72 h blocks of hippocampal EEGs obtained from C57BL/6 (WT), $\mathrm{Adk}^{\mathrm{fl} / \mathrm{fl}}$, and Nestin-Cre ${ }^{+/-}$mice without floxed $A d k$ alleles were compared with those from $\mathrm{Adk}^{\mathrm{\Delta brain}}$ mice $(n=5$, each) All control lines had normal hippocampal baseline EEGs, similar to those recorded from $\mathrm{Adk}^{\Delta \mathrm{brain}}$ mice. Neither the $\mathrm{Adk}^{\Delta \mathrm{brain}}$ mutation nor the NestinCre expression affected baseline EEG activity (Fig. 3A). During those initial recordings, spontaneous seizures were found only in the $\mathrm{Adk}^{\Delta \text { brain }}$ mice, not in the controls. Therefore, an additional $7 \mathrm{~d}$ of vEEG recording blocks in a new set of Adk ${ }^{\Delta \text { brain }}$ mice $(n=$ $6)$ and Nestin-Cre ${ }^{+/-}$mice $(n=4$; Fig. $3 B)$ were performed. Five of six Adk ${ }^{\Delta \text { brain }}$ mice had spontaneous seizures, whereas none of the controls was affected ( $\chi^{2}$ test of contingency, $\chi_{(1)}^{2}=6.67, z=$ $\left.2.58,{ }^{* *} p=0.0098\right)$. The spontaneous seizures were identified first on EEG and defined as high-amplitude rhythmic discharges that clearly represented a new pattern of tracing lasting for $>5 \mathrm{~s}$. The seizures identified by EEG always had a tonic-clonic behavioral correlate (Movie 3). The average spontaneous seizure rate assessed by vEEG was estimated to be 0.85 seizures per day with the average duration of each seizure being $43.6 \pm 7.4 \mathrm{~s}$.

\section{Brain-wide disruption of ADK results in learning and} memory impairment

Patients with ADK deficiency have severe cognitive impairments (Bjursell et al., 2011; Staufner et al., 2016); therefore, we next assessed learning and memory in our $\mathrm{Adk}^{\Delta{ }^{\Delta r a i n}}$ mice. $\mathrm{Adk}^{\Delta \mathrm{brain}}$ and $\mathrm{Adk}^{\mathrm{fl} / \mathrm{fl}}$ controls were subjected to a classic fear-conditioning paradigm in which a cue (CS) is paired with a mild electric foot shock. Adk ${ }^{\Delta \text { brain }}$ mice had severe cognitive impairments reflected by deficits in both associative learning and contextual memory compared with $\mathrm{Adk}^{\mathrm{fl} / \mathrm{fl}}$ mice (Fig. $4 A, B$ ). Associative learning was indexed by an increase in percentage time freezing during the CS, with CS1 being the first baseline tone response. $\mathrm{Adk}^{\mathrm{bbrain}}$ mice had a significant decrease in percentage time freezing during CS2 compared with $\mathrm{Adk}^{\mathrm{fl} / \mathrm{l}}$ mice (repeated-measures ANOVA, geno-

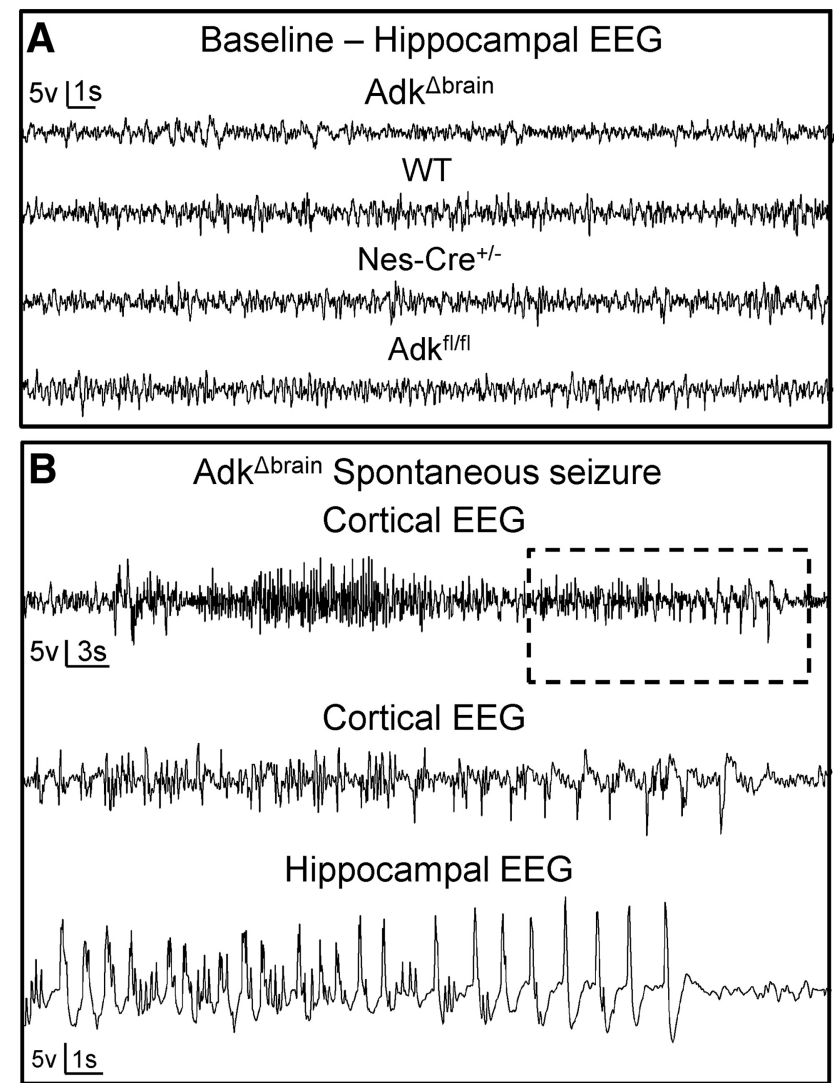

Figure 3. Loss of brain ADK results in spontaneous seizures. $\boldsymbol{A}$, Thirty seconds of representative hippocampal EEG traces from Adk ${ }^{\Delta \text { brain }}$ mice and C57BL6 (WT), Nestin-Cre ${ }^{+1-}$. $\mathrm{Adk}^{+/+}$(Nes-Cre ${ }^{+/-}$), and $\mathrm{Adk}^{\mathrm{fl} / \mathrm{fl}}$ control mice demonstrate comparable baseline seizure activity. $\boldsymbol{B}$, Representative cortical EEG recording of a complete spontaneous convulsive seizure (55 s) from an Adk ${ }^{\Delta \text { brain }}$ mouse (top trace). Bottom traces are high-resolution cortical and hippocampal EEG recordings of a 20 s portion of seizure demarcated by the box in top trace. See Movie 3 for a matching behavioral seizure.

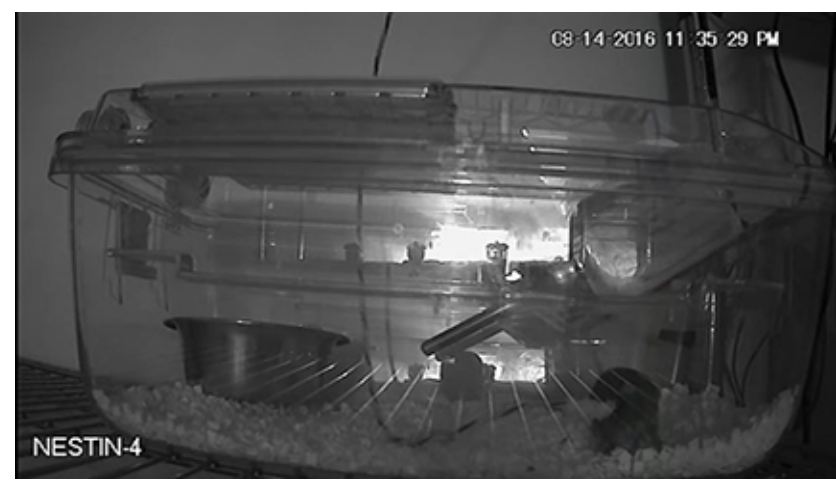

Movie 3. Spontaneous tonic convulsive seizure in an $\mathrm{Adk}^{\Delta \text { brain }}$ mouse. The movie is of a representative spontaneous seizure characterized by tonic-clonic activity. The seizure is the behavioral correlate of the cortical and hippocampal EEG traces shown in Figure $3 B$.

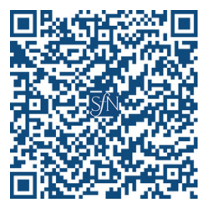

type effect $F_{(3,48)}=6.62 ;$ Adk $^{\Delta \text { brain }}$ vs $\operatorname{Adk}^{\mathrm{fl} / \mathrm{fl}} \# \# \#$ \#\# $<0.0001$; Fig. $4 A$ ). Even though $\mathrm{Adk}^{\Delta \text { brain }}$ mice had an associative learning deficit, they showed the general ability to learn, with a significant increase in freezing during CS3 and CS4, compared with CS1 (trial effect $F_{(3,144)}=60.99$; CS3 vs CS1 ${ }^{\star} p=0.0163$, CS4 vs CS1 ${ }_{* * *} p<0.0001$; Fig. $4 B$ ). Therefore, learning was considerably 

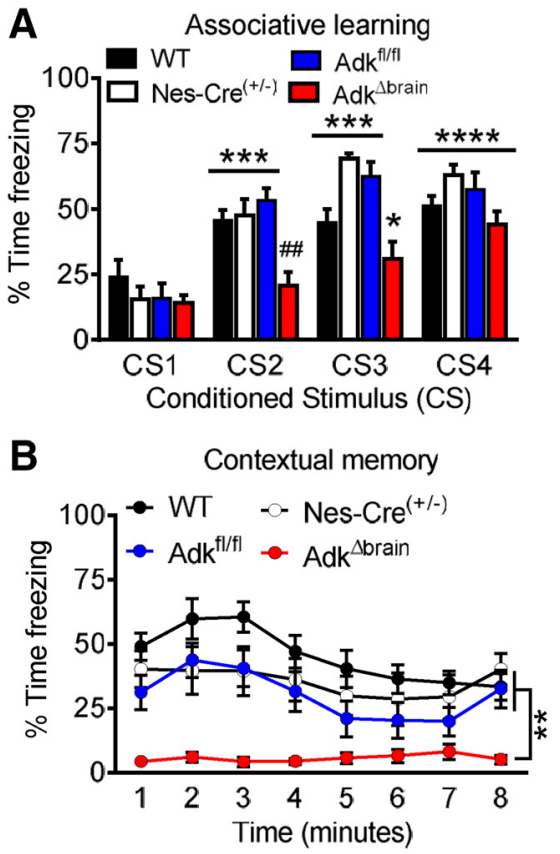

Figure 4. ADK deficiency in the brain results in cognitive impairment. $\boldsymbol{A}$, Associative learning in the conditioned freezing paradigm is significantly decreased during conditioned stimulus 2 (CS2) in Adk ${ }^{\Delta \text { brain }}(n=13)$ mice, compared with WT $(n=15)$, Nestin-Cre ${ }^{+/-}(n=10)$, and $\operatorname{Adk}^{\mathrm{fl} / \mathrm{fl}}(n=14)$ controls. Within Adk ${ }^{\Delta \text { brain }}$ mice, the percentage time freezing during CS3 and CS4 is significantly increased compared with baseline CS1 freezing. $\boldsymbol{B}$, Contextual freezing is significantly impaired in Adk ${ }^{\Delta \text { brain }}$ mice $(n=13)$, compared with WT $(n=15)$, Nestin$\mathrm{Cre}^{+/-}(n=10)$, and $\mathrm{Adk}^{\mathrm{fl} / \mathrm{fl}}(n=14)$ controls. Data are represented as the mean \pm SEM; ${ }^{*} p<0.05,{ }^{* *} p<0.01,{ }^{* * *} p<0.001,{ }^{* * * *} p<0.0001$, \#\#p $<0.01$.

delayed in $\mathrm{Adk}^{\mathrm{bbrain}}$ mice, compared with $\mathrm{Adk}^{\mathrm{f} / \mathrm{fl}}$ mice. Furthermore, $\mathrm{Adk}^{\Delta \mathrm{brain}}$ mice had a profound deficit in contextual memory as demonstrated by freezing rates comparable to baseline, which was significantly different from those observed in $\mathrm{Adk}^{\mathrm{fl} / \mathrm{fl}}$ mice (repeated-measures ANOVA, genotype effect $F_{(3,48)}=$ 13.41; $\mathrm{Adk}^{\mathrm{bbrain}}$ vs $\mathrm{Adk}^{\mathrm{f} / \mathrm{fl}{ }^{* *} p}=0.0024$; Fig. $4 B$ ). To rule out genotype-related confounds, we conducted fear conditioning between three control lines $\left(\mathrm{Adk}^{\mathrm{fl} / \mathrm{fl}}\right.$, Nestin-Cre ${ }^{+/-}$, and WT $\mathrm{C} 57 \mathrm{BL} / 6)$ and found that learning and memory deficits were not affected by either Cre or the floxed Adk allele (Fig. 4A,B). To rule out sensory-related confounds, we performed a basic behavioral screen and found no differences in the elevated plus maze, acoustic startle response, or spatial working memory tests in Adk ${ }^{\Delta \text { brain }}$ versus $\mathrm{Adk}^{\mathrm{f} / \mathrm{l}}$ mice (data not shown). Furthermore, the response to foot shock, indexed by average $(p=0.51)$ and maximum motion index $(p=0.38)$, was comparable between the $\mathrm{Adk}^{\Delta \text { brain }}$ mice and all controls (data not shown). Together, these data demonstrate that brain ADK deficiency is associated with hippocampus-dependent cognitive impairment.

$\mathrm{Adk}^{\Delta \text { brain }}$ mice have increased levels of synaptic adenosine To provide a mechanistic basis for the $\mathrm{Adk}^{\Delta \text { brain }}$ phenotype described above, we performed a detailed biochemical, pharmacological, and electrophysiological analysis of hippocampal brain slices derived from 4-month-old animals. Because ADK is the key metabolic route for adenosine clearance, we first tested for increased levels of brain adenosine. Due to the short half-life of adenosine and the need to gauge the magnitude of changes related to the synaptic pool of adenosine, we pursued a functional assay for synaptic adenosine by testing the influence of the $A_{1} R$ antagonist DPCPX on fEPSPs. We used a hippocampal slice preparation with stimulating electrodes placed in the CA3/CA1 border and recording electrodes placed in CA1 to study excitatory glutamatergic inputs to CA1 pyramidal neurons. We used a supramaximal concentration of DPCPX (50 nM) corresponding to $\sim 100 \times$ the $K_{\mathrm{i}}$ value for $\mathrm{A}_{1} \mathrm{Rs}$ (Lohse et al., 1988; Sebastião et al., 1990). In hippocampal slices from epileptic $\mathrm{Adk}^{\Delta \mathrm{brain}}$ mice, DPCPX induced a significant increase in the fEPSP slope of $118 \pm$ $20.1 \%$ compared with the predrug baseline (repeated-measures ANOVA, time effect $F_{(22,176)}=23.23 ; 10 \mathrm{~min}$ vs $0 \mathrm{~min} \# p=$ $0.022,12-38 \mathrm{~min}$ vs $0 \mathrm{~min} \# \# \# p<0.0001$; Fig. $5 A$ ). This value contrasts with that obtained from age-matched $\mathrm{Adk}^{\mathrm{f} / \mathrm{fl}}$ mice, in which DPCPX increased the fEPSP slope by only $22 \pm 7.8 \%$ (genotype effect $F_{(1,8)}=16.25$; $\mathrm{Adk}^{\Delta \text { brain }}$ vs $\mathrm{Adk}^{\mathrm{fl} / \mathrm{fl}{ }_{\star \star} p} p=0.0042$, Fig. $5 A$; unpaired $t$ test, $t_{(8)}=4.43,{ }^{* *} p=0.0022$, Fig. $\left.5 B\right)$. The higher disinhibition of synaptic transmission caused by the $A_{1} R$ antagonist in $\mathrm{Adk}^{\Delta \text { brain }}$ mice suggests an enhanced $\mathrm{A}_{1} \mathrm{R}$ mediated inhibitory tonus. Using calculations described previously (Dunwiddie and Diao, 1994), we estimated the extracellular adenosine levels in the Adk ${ }^{\Delta \text { brain }}$ brains to be in the $1 \mu \mathrm{M}$ range, whereas control levels of extracellular adenosine in $\mathrm{Adk}^{\mathrm{f} / \mathrm{fl}}$ mice were maintained at $\angle 200 \mathrm{~nm}$. To assess $A_{1} R$ levels and function, we first quantified $A_{1} R$ mRNA and protein from cortical lysates. qRT-PCR demonstrated significantly decreased $A_{1} R$ mRNA in Adk ${ }^{\text {bbain }}$ mice compared with controls (Mann-Whitney test, $U=0,{ }^{*} p=0.0095 ;$ Fig. $5 C$ ). $A_{1} R$ protein was assessed by saturation binding experiments using $\left[{ }^{3} \mathrm{H}\right] \mathrm{DPCPX}$, which allow quantification of the maximal number of binding sites $\left(B_{\max }\right)$ as well as the affinity (dissociation constant, $K_{\mathrm{d}}$ ) of the receptor for the ligand. Both parameters were obtained by nonlinear regression analysis. The $B_{\max }$ value indicated a significant reduction of functional $\mathrm{A}_{1}$ Rs in $\mathrm{Adk}^{\Delta \text { brain }}$ mice (unpaired $t$ test, $t_{(6)}=8.02$, ${ }^{* *} p=0.0002$; Fig. $\left.5 D\right)$. Based on the $K_{\mathrm{d}}$ values, there were no significant differences $(p>0.05)$ in the affinity of the receptor for its agonist between $\mathrm{Adk}^{\mathrm{f} / \mathrm{fl}}$ and $\mathrm{Adk}^{\Delta \text { brain }}$ mice $\left(K_{\mathrm{d}}: 4.8 \pm 0.9 \mathrm{vs}\right.$ $3.4 \pm 1.1 \mathrm{nM}$ ). These data suggest decreased $\mathrm{A}_{1} \mathrm{R}$ density, likely an adaptation to an increased synaptic adenosine tone in the Adk ${ }^{\Delta b r a i n}$ mice. Finally, to assess basal synaptic transmission in $\mathrm{Adk}^{\Delta \mathrm{brain}}$ mice, we performed input-output curve analysis by recording the fEPSP responses as a function of increased stimulation intensities delivered to hippocampal slices. The maximum fEPSP slope obtained from $\mathrm{Adk}^{\Delta \mathrm{brain}}$ slices was significantly higher than that from control slices (nonlinear regression fit; top

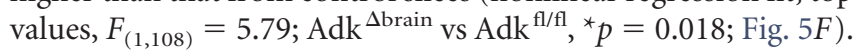
Together, the data demonstrate increased facilitatory action of DPCPX (Fig. $5 A$ ) in the $\mathrm{Adk}^{\mathrm{\Delta brain}}$ mice, a finding that supports our in vivo data (Fig. 2).

\section{Adk ${ }^{\Delta \text { brain }}$ mice have increased $A_{2 A}$ receptor-mediated synaptic plasticity}

Because synaptic levels of adenosine were found to be elevated in $\mathrm{Adk}^{\Delta \text { brain }}$ samples $(>1 \mu \mathrm{M})$, we anticipated increased $\mathrm{A}_{2 \mathrm{~A}} \mathrm{R}$ activation, although adenosine has a slightly lower potency at $\mathrm{A}_{2 \mathrm{~A}} \mathrm{Rs}$ $\left(\mathrm{EC}_{50}=0.7 \mu \mathrm{M}\right)$ compared with $\mathrm{A}_{1} \mathrm{Rs}\left(\mathrm{EC}_{50}=0.3 \mu \mathrm{M}\right.$; Fredholm et al., 2001). To test whether baseline $A_{2 A} R$ signaling was affected in Adk ${ }^{\Delta b r a i n}$ mice, we assessed fEPSPs recorded from hippocampal slices in the presence of a selective $A_{2 A} R$ agonist or antagonist. Neither the $\mathrm{A}_{2 \mathrm{~A}} \mathrm{R}$ agonist CGS21680 nor the antagonist SCH58261 had any effects on fEPSPs recorded from hippocampal $\mathrm{Adk}^{\Delta \text { brain }}$ or $\mathrm{Adk}^{\mathrm{fl} / \mathrm{fl}}$ slices (repeated-measures ANOVA; $\mathrm{Adk}^{\Delta \mathrm{brain}} \mathrm{vs} \mathrm{Adk}^{\mathrm{f} / \mathrm{fl}}(A) F_{(1,6)}=2.58, p=0.16$, Fig. $6 A ; F_{(4,108)}=$ $0.029, p=0.87$, Fig. $6 B)$. Next, we tested whether the ADK deletion would affect the tonic influence of $\mathrm{A}_{2 \mathrm{~A}}$ Rs on LTP. Consistent with previous reports using mild theta-burst LTP induction 
(Costenla et al., 2011), $\mathrm{A}_{2 \mathrm{~A}} \mathrm{R}$ blockade was virtually devoid of effect on LTP magnitude, the fEPSP slope $60 \mathrm{~min}$ after LTP induction being $122 \pm 4.0 \%$ in control compared with $124 \pm 4.5$ in SCH58261 (repeated-measures ANOVA, treatment effect $F_{(1,8)}=0.036$, control vs SCH58261, $p=0.85$; Fig. $6 C$ ). When comparing LTP magnitude in the absence of any drug in $\mathrm{Adk}^{\mathrm{fl} / \mathrm{fl}}$ versus $\mathrm{Adk}^{\Delta \text { brain }}$ slices, a significant increase in LTP was detected (fEPSP: $122 \pm 4.0 \%$ vs $152 \pm 6.9 \%$; two-way ANOVA, interaction $F_{(1,16)}=14.36$, $\operatorname{Adk}^{\mathrm{f} / \mathrm{fl}}$ vs Adk ${ }^{\Delta \text { brain }}{ }^{* *} p=0.0053$; Fig. $6 E$ ). Remarkably, the presence of SCH58261 in $\mathrm{Adk}^{\Delta \text { brain }}$ slices reversed the LTP magnitude (fEPSP: $113 \pm 5.6 \%$ ) toward values close to the $\mathrm{Adk}^{\mathrm{fl} / \mathrm{fl}}$ mice (repeated-measures ANOVA, treatment effect $F_{(1,8)}=17.0$, control vs SCH58261, ${ }^{* *} p=$ 0.0033 , Fig. $6 E$; Adk ${ }^{\Delta \text { brain }}$ control vs SCH58261, ${ }^{* * *} p=0.0005$; Fig. $6 F$ ), suggesting that $\mathrm{Adk}^{\Delta \text { brain }}$ mice have enhanced tonic $\mathrm{A}_{2 \mathrm{~A}} \mathrm{R}$ activation leading to increased synaptic plasticity.

\section{BDNF signaling is increased in Adk $^{\Delta \text { brain }}$ mice}

High-frequency stimulation triggers the release of BDNF and ATP, the major metabolic precursor of adenosine, therefore favoring the activation of $\mathrm{A}_{2 \mathrm{~A}}$ Rs, which in turn gate $\operatorname{TrkB}$ receptor-mediated facilitatory actions of BDNF upon LTP (Fontinha et al., 2008; Dias et al., 2013). Taking into account the increased LTP magnitude in $\mathrm{Adk}^{\Delta \text { brain }}$ animals and the prevention of this increase on $\mathrm{A}_{2 \mathrm{~A}} \mathrm{R}$ blockade, we next assessed whether the LTP increase in Adk ${ }^{\Delta \text { brain }}$ mice could result from enhanced BDNF signaling. To test this hypothesis, the tyrosine kinase inhibitor K252a (200 nM) was added to the perfusion solution and LTP was induced as before. K252a restored normal theta-burst-induced LTP in $\mathrm{Adk}^{\Delta \text { brain }}$ slices (absence: $150 \pm 6.7 \%$ vs presence: $101 \pm 7.0 \%, n=5$ mice). Therefore, in Adk ${ }^{\Delta \text { brain }}$ mice, the magnitude of LTP in slices in the presence of $\mathrm{K} 252 \mathrm{a}$ was abolished (repeated-measures ANOVA, treatment effect, $F_{(1,4)}=19.82$, control vs K252a, ${ }^{\star} p=$ 0.012; Fig. $6 F$ ). K252a had virtually no effect on LTP magnitude in $\mathrm{Adk}^{\mathrm{fl} / \mathrm{fl}}$ mice (data not shown), in agreement with data reported for wild-type rats (Fontinha et al., 2008). These results suggest a higher level of TrkB receptor activation accounting for a larger LTP in the Adk ${ }^{\Delta \text { brain }}$ mice. Therefore, our results indicate that the enhanced LTP in Adk ${ }^{\Delta \text { brain }}$ mice can be attributed to a higher influence of endogenous BDNF on LTP. Finally, we determined that $A \mathrm{dk}^{\Delta \text { brain }}$ mice do not compensate for increased BDNF signaling with changes in TrkB receptor expression $(n=$ 8/genotype, unpaired $t$ test, $t_{(14)}=0.96, p=0.36$; Fig. $\left.6 H\right)$. However, we observed a modest, but insignificant, decrease in the ratio of full-length $\mathrm{TrkB}$ receptor to truncated $\operatorname{TrkB}$ receptor (unpaired $t$ test, $t_{(14)}=1.68, p=0.11$; Fig. $6 H$ ).

\section{$\mathrm{A}_{2 \mathrm{~A}} \mathrm{R}$ blockade ameliorates the inducible seizure phenotype and cognitive impairment in Adk ${ }^{\Delta \text { brain }}$ mice}

Increased $\mathrm{A}_{2 \mathrm{~A}} \mathrm{R}$ activation, as identified here, may promote seizures in $\mathrm{Adk}^{\Delta \text { brain }}$ mice through a BDNF-mediated mechanism.
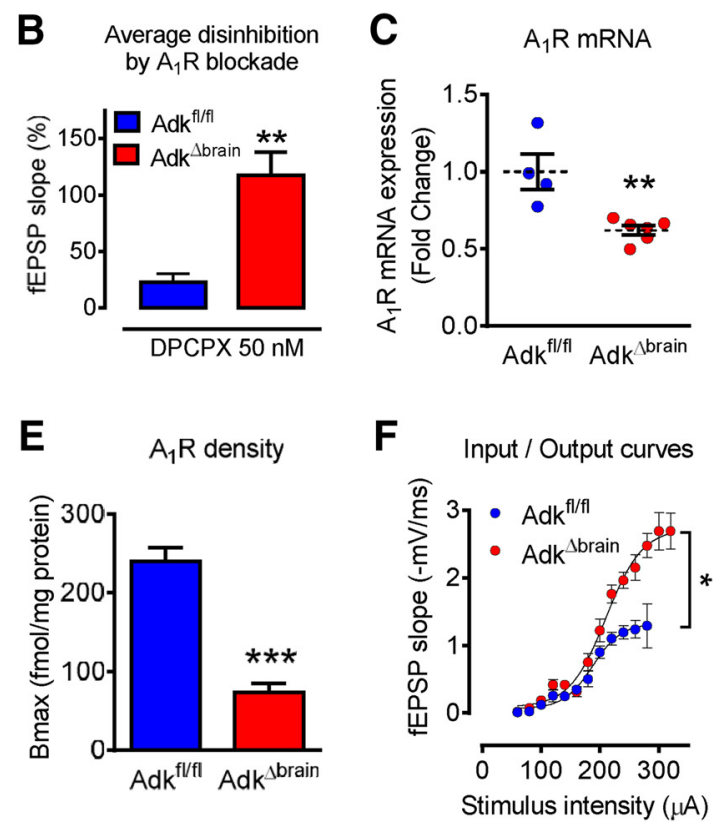

Figure 5. $A d k^{\Delta \text { brain }}$ mice have increased synaptic adenosine. $A$, Disinhibition of synaptic transmission by the $A_{1} R$ antagonist versus baseline. $\boldsymbol{B}$, Percentage change in fEPSP slope during the last $10 \mathrm{~min}$ of DPCPX. $\boldsymbol{C}$, Decreased $A_{1} R \mathrm{mRNA}$ levels of Adk ${ }^{\Delta \text { brain }}$ ( 6 ) versus $A d k^{\mathrm{fl} / \mathrm{fl}}$ ( $n=4$ mice) cortex. D, Binding curve for $\left[{ }^{3} \mathrm{H}\right] \mathrm{DPCPX}$ is reduced the $A d \mathrm{dk}^{\Delta{ }^{\mathrm{brain}}}$ versus $\mathrm{Adk}{ }^{\mathrm{fl} / \mathrm{fl}}$ cortex $(n=4$ 作 The input- output curves correspond to responses generated by increasing stimulation intensities $(60-340 \mathrm{~mA})$ in Adk ${ }^{\mathrm{fl} / \mathrm{f}}$ $(n=5)$ and $A_{d k}{ }^{\Delta \text { brain }}(n=5)$ mice. Results are shown as the mean \pm SEM and statistical analysis was performed using an $F$ test

In this case, $\mathrm{A}_{2 \mathrm{~A}} \mathrm{R}$ antagonists or TrkB antagonists might be of therapeutic value. Furthermore, the balance between inhibitory $\mathrm{A}_{1}$ Rs and stimulatory $\mathrm{A}_{2 \mathrm{~A}}$ Rs is one of the factors that determine the susceptibility to seizures (Sebastião and Ribeiro, 2009; Gomes et al., 2011; Chen et al., 2013). We therefore tested whether $A_{2 \mathrm{~A}} \mathrm{Rs}$ play a role in determining seizure thresholds in $\mathrm{Adk}^{\Delta{ }^{\Delta r a i n}}$ mice by first administering a single injection of the $\mathrm{A}_{2 \mathrm{~A}} \mathrm{R}$ agonist $5^{\prime}-(\mathrm{N}$ cyclopropyl)carboxamidoadenosine (CPCA, $0.5 \mathrm{mg} / \mathrm{kg}$ ). CPCA was ineffective at inducing a seizure (data not shown), which may be indicative of a ceiling effect for $\mathrm{A}_{2 \mathrm{~A}} \mathrm{R}$ activation in $\mathrm{Adk}^{\Delta \text { brain }}$ mice. To circumvent this, we next sought to focus on the effect of blocking $\mathrm{A}_{2 \mathrm{~A}} \mathrm{R}$ activity. Pretreatment with antagonists to both $\mathrm{A}_{2 \mathrm{~A}} \mathrm{Rs}$ (SCH58261) and TrkB (Ana-12) significantly extended the survival time after DPCPX-induced seizures in Adk ${ }^{\Delta \text { brain }}$ mice, compared with vehicle-treated controls (Mantel-Cox test, $\chi_{(2)}^{2}=12.51,{ }^{\star *} p<$ 0.0019; Fig. 7A). Adk ${ }^{\Delta \text { brain }}$ mice that received vehicle injections in lieu of DPCPX and Adk ${ }^{\mathrm{fl} / \mathrm{fl}}$ mice that received vehicle, $\mathrm{SCH} 58261$, or Ana-12 \pm DPCPX did not have seizures (data not shown). Next, we generated Nestin-Cre:Adk ${ }^{\mathrm{fl} / \mathrm{fl}}: \mathrm{A}_{1} \mathrm{R}^{-/-}\left(=\mathrm{Adk}^{\Delta \mathrm{brain}} \mathrm{A}_{1} \mathrm{R}^{-/-}\right)$and Nestin-Cre: $\mathrm{Adk}^{\mathrm{fl} / \mathrm{fl}}: \mathrm{A}_{2 \mathrm{~A}} \mathrm{R}^{-/-}\left(=\mathrm{Adk}^{\Delta \text { brain }} \mathrm{A}_{2 \mathrm{~A}} \mathrm{R}^{-/-}\right)$triple mutants. Importantly, $\mathrm{Adk}^{\Delta \mathrm{brain}} \mathrm{A}_{1} \mathrm{R}^{-/-}$mice maintained their stressinduced seizure phenotype while exhibiting increased mortality, whereas $\mathrm{Adk}^{\Delta \text { brain }} \mathrm{A}_{2 \mathrm{~A}} \mathrm{R}^{-1-}$ mice showed a marked resistance to stress-induced seizures and normal life expectancy ( $\chi^{2}$ test of contingency, $\chi_{(2)}^{2}=18.26,{ }^{\star * *} p=0.0001$, Fig. $7 C$; Mantel-Cox test, $\chi_{(2)}^{2}=26.51,{ }^{* * *} p<0.0001$, Fig. $\left.7 B\right)$. Together, these data suggest that $\mathrm{Adk}^{\Delta \text { brain }}$ mice have an enhanced $\mathrm{A}_{1} \mathrm{R}$-mediated protective tonus and that additional factors such as stress, $A_{1} R$ blockade, and increased $\mathrm{A}_{2 \mathrm{~A}} \mathrm{R}$ activation are needed to overcome this hurdle and allow the emergence of induced seizures. 
A

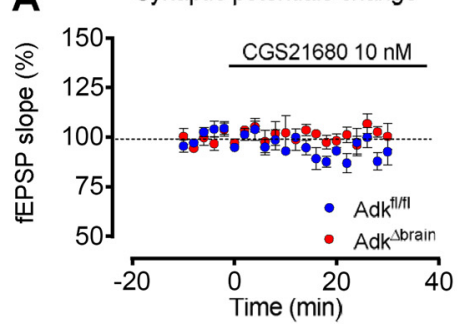

C

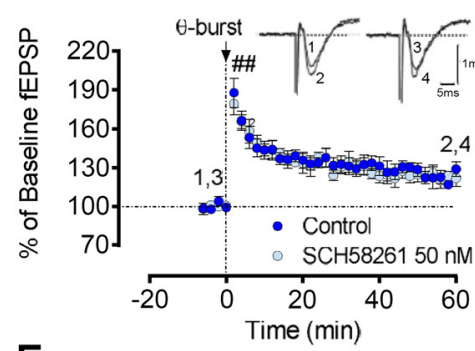

E

Average LTP magnitudes

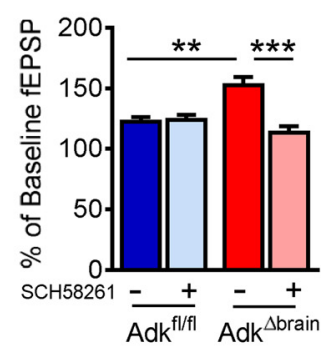

G

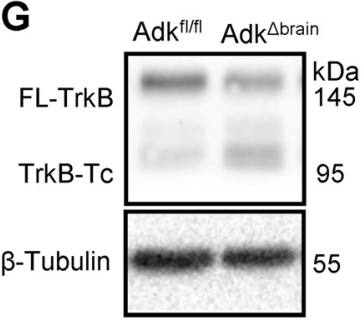

H TrkB receptor
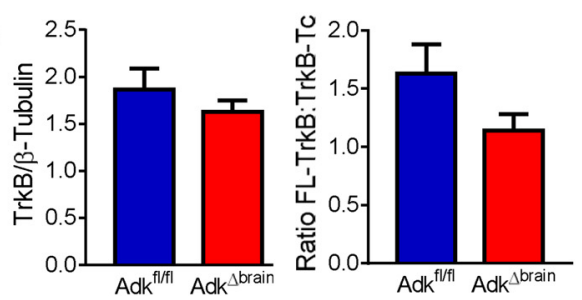

Figure 6. Adk ${ }^{\Delta \text { brain }}$ mice show enhanced $A_{2 A}$ and TrkB receptor-dependent LTP. A, B, The $A_{2 A} R$-selective agonist CGS21680 (10 nM) and antagonist SCH58261 (50 nM) does not affect the fEPSP slope in Adk ${ }^{\mathrm{flffl}}$ and Adk ${ }^{\Delta \text { brain }}$ slices ( $n=4$ mice/genotype/drug). $\boldsymbol{C}-\boldsymbol{E}, \mathbf{S C H} 58261$ restores normal theta-burst $(3 \times 3)$-induced LTP in Adk ${ }^{\Delta \text { brain }}$ mice. $\boldsymbol{C}, \boldsymbol{D}$, Average change in fEPSP slopes in the absence versus presence of SCH58261 in $\mathrm{Adk}^{\mathrm{fl} / \mathrm{fl}}(\boldsymbol{C})$ and $\mathrm{Adk}^{\Delta \text { brain }}(\boldsymbol{D})$ slices ( $n=5$ mice/genotype/drug). $\boldsymbol{E}$, Percentage of change in the fEPSP slopes recorded at 52-60 min after LTP induction. $\boldsymbol{F}$, The TrkB inhibitor K252a (200 nM) restores normal theta-burst $(3 \times 3)$-induced LTP in Adk ${ }^{\Delta \text { brain }}$ slices (absence: $150 \pm 6.7 \%$ vs presence: $101 \pm 7.0 \%, n=5$ mice each,). Insets in $\boldsymbol{C}, \boldsymbol{D}$, and $\boldsymbol{F}$ are representative traces of six consecutive responses composed of the stimulus artifact, presynaptic volley, and fEPSP obtained before $(\mathbf{1}, 3)$ and after $(2,4)$ the theta-burst stimuli in the absence $(\mathbf{1}, 2)$ and presence $(3,4)$ of drug. LTP was significant (\#\#\#\#) after theta-burst stimuli versus baseline $(\boldsymbol{C}, \boldsymbol{D}, \boldsymbol{F}) . \mathbf{G}$, Representative blot of full-length TrkB receptor (FL-TrkB, $145 \mathrm{kDa}$ ), truncated TrkB receptor (TrkB-Tc, $95 \mathrm{kDa}$ ), and $\beta$-tubulin ( $55 \mathrm{kDa}$, loading control) is shown. $\boldsymbol{H}$, Averaged immunodensities of TrkB receptor normalized to $\beta$-tubulin and the ratio of FL-TrkB to TrkB-Tc ( $n=8$ mice/genotype). Results are presented as mean \pm SEM. $100 \%$ corresponds to the averaged fEPSP slope recorded $10 \mathrm{~min}$ before LTP induction. ${ }^{*} p<0.05,{ }^{* *} p<0.01$, \#\#\#\#p $<0.0001$.

To establish whether the $\mathrm{A}_{2 \mathrm{~A}} \mathrm{R}$ is a target for the treatment of cognitive impairment in ADK deficiency, we tested $\mathrm{Adk}^{\Delta \mathrm{brain}}$ : $\mathrm{A}_{2 \mathrm{~A}} \mathrm{R}^{-1-}$ mice in the fear-conditioning paradigm. Remarkably, the deletion of $\mathrm{A}_{2 \mathrm{~A}} \mathrm{Rs}$ from $\mathrm{Adk}{ }^{\Delta b r a i n}$ mice restored hippocampus-dependent associative learning $\left(\right.$ ANOVA, $F_{(2,35)}=$ 15.94; $\mathrm{Adk}^{\Delta \mathrm{brain}^{2}}$ vs Adk ${ }^{\Delta \text { brain }}: \mathrm{A}_{2 \mathrm{~A}} \mathrm{R}^{-1-},{ }^{* * *} p=0.0008, \mathrm{Adk}^{\mathrm{H} / \mathrm{l}}$ vs Adk ${ }^{\Delta \text { brain }}: \mathrm{A}_{2 \mathrm{~A}} \mathrm{R}^{-1-}, p=0.43$; Fig. $7 D$ ) and contextual memory (Kruskal-Wallis statistic $=27.54 ; \mathrm{Adk}^{\Delta \text { brain }}$ vs $\mathrm{Adk}^{\Delta \text { brain }}$ : $\mathrm{A}_{2 \mathrm{~A}} \mathrm{R}^{-/-},{ }^{* * *} p<0.0001, \mathrm{Adk}^{\mathrm{f} / / \mathrm{fl}}$ vs $\mathrm{Adk}^{\Delta \text { brain }^{*}}: \mathrm{A}_{2 \mathrm{~A}} \mathrm{R}^{-1-}, p=$ 0.11 ; Fig. $7 E)$ to $A d k^{f / / f l}$ control levels. Together, our findings suggest that the $\mathrm{A}_{2 \mathrm{~A}} \mathrm{R}$ might be a therapeutic target for the treat- ment of the neurological phenotypes associated with ADK deficiency.

\section{Discussion}

We generated a novel mouse line, $\mathrm{Adk}^{\Delta \mathrm{brain}}$, to study specifically the neurological symptoms associated with global ADK deficiency such as those observed in human patients with mutations in the Adk gene (Bjursell et al., 2011; Staufner et al., 2016). We describe a novel mechanism by which ADK deficiency in the brain leads to neuronal adaptation processes that trigger enhanced $\mathrm{A}_{2 \mathrm{~A}} \mathrm{R}$ - and BDNF-dependent synaptic plasticity. Together, those adaptive processes cause a phenotype characterized by increased propensity to induced and spontaneous seizures and impairment in hippocampus-specific cognitive domains. Therefore, our findings suggest that global ADK deficiency has direct implications on neurological outcome parameters, which might be amenable to treatment. Importantly, we demonstrate that the genetic and pharmacological blockade of $\mathrm{A}_{2 \mathrm{~A}}$ Rs ameliorates the seizure phenotype and cognitive impairment in $\mathrm{Adk}^{\Delta \mathrm{brain}}$ mice. Several aspects of our study warrant further discussion.

\section{Loss of ADK function}

Human patients with global ADK deficiency due to homozygosity of point mutations located in the coding sequence of the ADK gene are rare, with only $17 \mathrm{pa}-$ tients from 11 independent families identified to date (Bjursell et al., 2011; Staufner et al., 2016). Human ADK deficiency shares certain characteristics with a global deletion of ADK in the mouse (Boison et al., 2002b). Both conditions are characterized by disruption of the transmethylation pathway resulting in major physiological aberrations of liver metabolism. Liver is the organ in which $85 \%$ of all transmethylation reactions in the body take place and it is also the organ with the highest expression levels of ADK. In the mouse, homozygous deletion of the Adk gene leads to microvesicular hepatic steatosis, whereas the human condition is characterized by hepatic encephalopathy, developmental delay, cognitive impairment, and seizures (Boison et al., 2002b; Bjursell et al., 2011; Staufner et al., 2016). Because global ADK knock-out mice do not survive into adulthood, it was not possible to investigate direct consequences of ADK deficiency on brain physiology. Because Adk expression in the liver of $A \mathrm{dk}^{\Delta \mathrm{brain}}$ mice is normal and heterozygous $A d k$ knock-out $\left(A d k^{+/-}\right)$have a normal liver despite a 50\% reduction in liver ADK expression (Boison et al., 2002b), the increased brain adenosine levels in Adk ${ }^{\Delta \text { brain }}$ mice are not likely to translate into increased peripheral levels of adenosine that affect liver physiology. Our present study with $\mathrm{Adk}^{\Delta \text { brain }}$ mice, in 
A

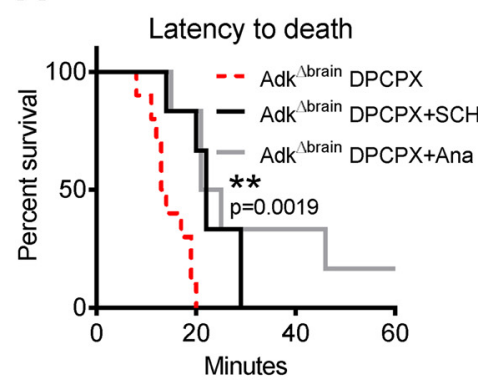

B

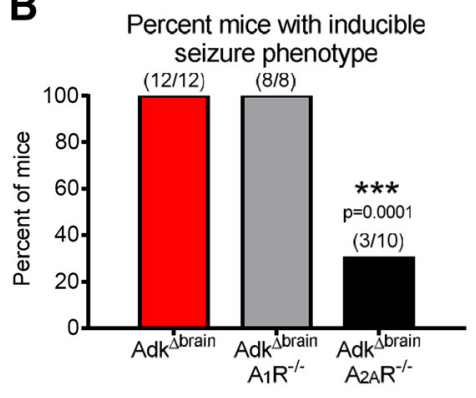

C

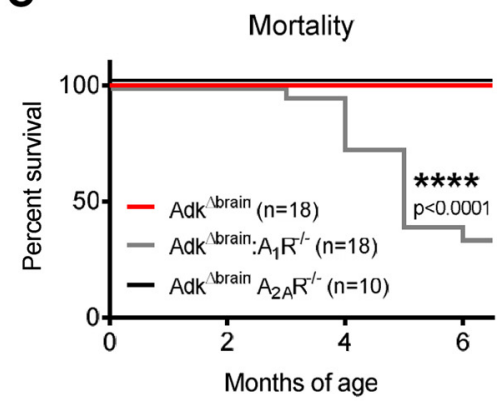

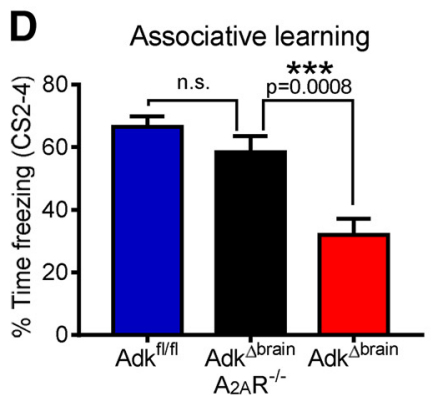

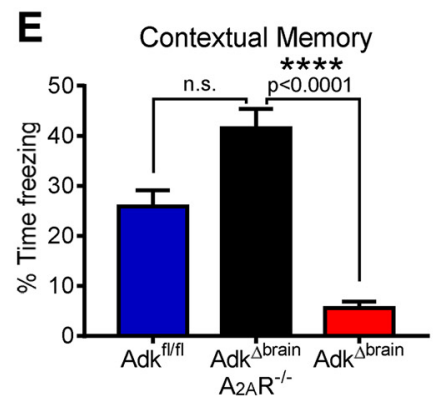

Figure 7. Blockade of $\mathrm{A}_{2 \mathrm{~A}}$ Ractivity ameliorates the inducible seizure phenotype and cognitive impairment in Adk ${ }^{\Delta \text { brain }}$ mice. $A$, Increased survival time of Adk ${ }^{\Delta b r a i n}$ mice treated with $S C H 58261$ $(0.5 \mathrm{mg} / \mathrm{kg}$, i.p., $30 \mathrm{~min}$ in advance, $n=6)$ or Ana- $12(0.5 \mathrm{mg} / \mathrm{kg}$, i.p., $4 \mathrm{~h}$ in advance, $n=6)$ before the DPCPX ( $3 \mathrm{mg} / \mathrm{kg}$, i.p.) challenge compared with DPCPX controls $(n=10)$. $\boldsymbol{B}$, Contingency

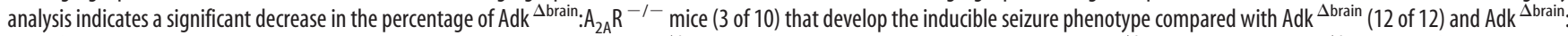
$A_{1} R^{-I-}\left(8\right.$ of 8) mice. C, Kaplan-Meier survival curve indicating increased Adk ${ }^{\Delta \text { brain }}: A_{1} R^{-I-}(n=18)$ mortality compared with $\operatorname{Adk}^{\Delta \text { brain }}(n=18)$ and Adk ${ }^{\Delta \text { brain }}: A_{2 A} R^{-\prime-}(n=10)$. D, Associative learning indexed as total percentage time freezing during the CS $2-4$ is restored to $\mathrm{Adk}^{\mathrm{flff}}(n=13)$ control levels in Adk ${ }^{\Delta \text { brain }} \mathrm{A}_{2 \mathrm{~A}} \mathrm{R}^{-/-}(n=12)$ mice and is significantly increased compared with $\mathrm{Adk}^{\Delta \mathrm{brain}}(n=13)$ mice. $E$, Contextual memory indexed as total percentage time freezing during the 8 min contextual freezing trial is significantly increased in $A_{d k}{ }^{\Delta b_{r a i n}} A_{2 A} R^{-I-}$ $(n=12)$ and $\operatorname{Adk}^{\mathrm{fl} / \mathrm{fl}}(n=13)$ mice, compared with $\operatorname{Adk}^{\Delta \text { brain }}(n=13)$ mice. Data are represented as the mean \pm SEM; ${ }^{* *} p<0.01,{ }^{* * *} p<0.001,{ }^{* * * *} p<0.0001$.

which development is not compromised by liver pathology, reveals a novel mechanism by which brain-wide ADK deficiency leads to neuronal adaptation processes resulting in increased $\mathrm{A}_{2 \mathrm{~A}} \mathrm{R}$-dependent synaptic plasticity. We propose that similar mechanisms might play a role for seizure generation and the complex behavioral phenotype of human patients with inborn ADK deficiency. Given the enormous size of the ADK gene (546 $\mathrm{kb}$ in humans), it is surprising that only few patients with mutations this gene have been described so far. High evolutionary conservation of the Adk cDNA ( $>80 \%$ identical between man and rodents) suggests that mutations are rarely tolerated. Given the robust neurological phenotype described in homozygous human ADK deficiency (Bjursell et al., 2011; Staufner et al., 2016) and in mice with a homozygous deletion of the Adk gene in the brain, as described here, it remains to be determined whether heterozygosity of Adk gene mutations might affect the development of epilepsy or psychiatric disorders in the human population.

\section{Gain vs loss of ADK function}

Although no human gain-of-function mutations for the $A d k$ gene have been described, ADK expression is subject to dynamic regulation during the course of epileptogenesis (Boison, 2008). Astrocytic ADK expression is significantly increased in the epileptogenic hippocampus of patients with epilepsy, as well as in rodent models of epilepsy (Boison, 2013), and is thought to be intrinsically linked to the development of epilepsy (WilliamsKarnesky et al., 2013). Both transgenic overexpression of ADK (Li et al., 2008) and adeno-associated virus-mediated overexpression of ADK in astrocytes (Shen et al., 2014) are sufficient to induce spontaneous recurrent seizures in mice. This ADK gainof-function-related seizure phenotype has been linked to adeno- sine deficiency and insufficient activation of adenosine $A_{1} R s$ (Gouder et al., 2004; Fedele et al., 2006). Seizure susceptibility is controlled, not only by the availability of adenosine (i.e., the synaptic adenosine pool), but also by the balance of inhibitory $A_{1} R$ activation versus stimulatory $\mathrm{A}_{2 \mathrm{~A}} \mathrm{R}$ activation, different distribution patterns of the receptors in the brain, and different potencies of adenosine on the two receptor types (Sebastião and Ribeiro, 2009; Gomes et al., 2011; Chen et al., 2013; Boison, 2016a). Effects mediated by the two receptors are discussed in more detail below.

\section{$A_{1} R$-dependent effects}

Evidence for an inverse relation between ADK expression and adenosine levels has been provided previously (Shen et al., 2011). The synaptic potential recordings reported here (Fig. 5) also revealed a higher synaptic adenosine tonus in epileptic $\mathrm{Adk}^{\Delta \mathrm{brain}}$ mice compared with aged-matched controls because the $A_{1} R$ antagonist DPCPX caused a more pronounced disinhibition of synaptic transmission in $\mathrm{Adk}^{\Delta b r a i n}$ mice despite the lower expression levels of the $A_{1} R$ and the lower inhibitory effect of $A_{1} R$ agonists on synaptic transmission. Consistent with those findings, we show that a low dose of DPCPX can induce seizures in Adk ${ }^{\Delta \text { brain }}$ mice that are remarkably similar to the stress-induced seizure phenotype (cf. Movies 1, 2).

\section{$\mathrm{A}_{2 \mathrm{~A}} \mathrm{R}$-dependent effects}

Brain-specific deletion of $A D K$ increased $A_{2 A} R$ function. Interestingly, $\mathrm{Adk}^{\Delta \mathrm{brain}}$ mice expressed a significantly larger LTP magnitude, which was prevented in the presence of an $A_{2 A} R$ antagonist, suggesting a higher tonic influence of this receptor in synaptic plasticity modulation. $\mathrm{A}_{2 \mathrm{~A}} \mathrm{R}$ antagonists do not affect basal synaptic transmission in hippocampal slices (Sebastião and Ribeiro, 1992; Cunha et al., 1997), which suggests only a minor 
role of the $A_{2 A} R$ as a regulator of hippocampal synaptic transmission under low-frequency neuronal firing. However, the release of purines is more pronounced during physiologically relevant patterns of neuronal activity, namely those that induce hippocampal LTP (Wieraszko and Seyfried, 1989). Adenosine formed from released ATP activates $\mathrm{A}_{2 \mathrm{~A}}$ Rs preferentially (Cunha et al., 1996). All of these factors favor an influence of $A_{2 A} R$ activation on synaptic plasticity. Our data show that these effects, which also result from increased $\mathrm{A}_{2 \mathrm{~A}} \mathrm{R} / \mathrm{BDNF}$ signaling (see below), are markedly exacerbated in $\mathrm{Adk}^{\Delta \mathrm{brain}}$ mice.

Our findings of cognitive impairment in $\mathrm{Adk}^{\mathrm{\Delta brain}}$ mice are consistent with hippocampus-dependent memory deficits in transgenic rats with overexpression of the $\mathrm{A}_{2 \mathrm{~A}} \mathrm{R}$ in the hippocampus and cortical brain structures (Giménez-Llort et al., 2007). Remarkably, enhanced LTP, together with enhanced $\mathrm{A}_{2 \mathrm{~A}} \mathrm{R}$ and $\mathrm{BDNF}$ signaling, is associated with impaired learning and memory (Diógenes et al., 2011). Here, we show that the genetic ablation of $\mathrm{A}_{2 \mathrm{~A}} \mathrm{Rs}$ restores cognitive function in $\mathrm{Adk}^{\Delta \text { brain }}$ mice. These findings demonstrate directly that increased $\mathrm{A}_{2 \mathrm{~A}} \mathrm{R}$ activity in $\mathrm{Adk}^{\mathrm{\Delta brain}}$ mice may precipitate the impaired learning and memory phenotype. Increased $\mathrm{A}_{2 \mathrm{~A}} \mathrm{R}$ function is also consistent with previous findings in the kindling model of epilepsy, in which a long-term increased density of $\mathrm{A}_{2 \mathrm{~A}}$ Rs was observed (Rebola et al., 2003). Consistent with the anti-epileptic effects of an $A_{2 A} R$ antagonist (Etherington and Frenguelli, 2004), $\mathrm{A}_{2 \mathrm{~A}} \mathrm{R}$ knock-out mice are partially protected from convulsive activity in some experimental models of epilepsy (El Yacoubi et al., 2009). Therefore, enhanced $A_{2 A} R$ signaling (Fig. 6) in addition to inhibitory $A_{1} R$ activation (Fig. 5) resulting in an imbalance of $A_{1} R / A_{2 A} R$ signaling is a plausible mechanism to permit a "breakthrough" of seizures in an otherwise protected brain environment in $\mathrm{Adk}^{\Delta \mathrm{brain}}$ mice.

\section{BDNF-dependent effects}

Our findings of enhanced BDNF-dependent plasticity in $\mathrm{Adk}^{\Delta \mathrm{brain}}$ mice are related to those from BDNF-overexpressing mice (BDNF-tg mice), which likewise develop stress-induced seizures triggered by placing the animals into a new cage. This seizure phenotype only develops later in life, at 5-6 months after birth (Papaleo et al., 2011). In our mechanistic study, we demonstrate that the enhanced $\mathrm{A}_{2 \mathrm{~A}} \mathrm{R}$ activity in $\mathrm{Adk}{ }^{\Delta \text { brain }}$ mice leads to increased tonic activation of TrkB receptors by BDNF, thereby inducing enhanced synaptic plasticity. Adenosine, through $A_{2 A} R$ activation, is an upstream regulator of BDNF-mediated synaptic plasticity (Fontinha et al., 2008; Sebastião and Ribeiro, 2015). Through activation of TrkB, BDNF has facilitatory actions on neuronal activity and synaptic plasticity by operating a cascade of events that lead to imbalanced excitatory transmission (Leal et al., 2015).

\section{Therapeutic implications}

Our findings strongly suggest that blocking the $\mathrm{A}_{2 \mathrm{~A}} \mathrm{R}$ might be of therapeutic value for the treatment of neurological symptoms in ADK-deficient patients. We show here that the pharmacological and genetic ablation of $\mathrm{A}_{2 \mathrm{~A}} \mathrm{R}$ function ameliorates the seizure phenotype of $A d k^{\Delta \text { brain }}$ mice. Importantly, the genetic deletion of the $\mathrm{A}_{2 \mathrm{~A}} \mathrm{R}$ restores hippocampus-dependent learning and memory functions in $A d k^{\Delta b r a i n}$ mice. This is a significant finding of translational significance because $\mathrm{A}_{2 \mathrm{~A}} \mathrm{R}$ inhibitors are in clinical development for the treatment of motor symptoms in Parkinson's disease (Schwarzschild, 2007). We show that those agents might also have procognitive effects under conditions of enhanced adenosine levels in the brain.

\section{References}

Batalha VL, Pego JM, Fontinha BM, Costenla AR, Valadas JS, Baqi Y, Radjainia H, Müller CE, Sebastião AM, Lopes LV (2013) Adenosine A(2A) receptor blockade reverts hippocampal stress-induced deficits and restores corticosterone circadian oscillation. Mol Psychiatry 18:320-331. CrossRef Medline

Bjursell MK, Blom HJ, Cayuela JA, Engvall ML, Lesko N, Balasubramaniam S, Brandberg G, Halldin M, Falkenberg M, Jakobs C, Smith D, Struys E, von Döbeln U, Gustafsson CM, Lundeberg J, Wedell A (2011) Adenosine kinase deficiency disrupts the methionine cycle and causes hypermethioninemia, encephalopathy, and abnormal liver function. Am J Hum Genet 89:507-515. CrossRef Medline

Boison D (2008) The adenosine kinase hypothesis of epileptogenesis. Prog Neurobiol 84:249-262. CrossRef Medline

Boison D (2013) Adenosine kinase: exploitation for therapeutic gain. Pharmacol Rev 65:906-943. CrossRef Medline

Boison D (2016a) Adenosinergic signaling in epilepsy. Neuropharmacology 104:131-139. Medline

Boison D (2016b) The biochemistry and epigenetics of epilepsy: focus on adenosine and glycine. Front Mol Neurosci 9:26. CrossRef Medline

Boison D, Huber A, Padrun V, Déglon N, Aebischer P, Möhler H (2002a) Seizure suppression by adenosine-releasing cells is independent of seizure frequency. Epilepsia 43:788-796. CrossRef Medline

Boison D, Scheurer L, Zumsteg V, Rülicke T, Litynski P, Fowler B, Brandner S, Möhler H (2002b) Neonatal hepatic steatosis by disruption of the adenosine kinase gene. Proc Natl Acad Sci U S A 99:6985-6990. CrossRef Medline

Boison D, Singer P, Shen HY, Feldon J, Yee BK (2012) Adenosine hypothesis of schizophrenia: opportunities for pharmacotherapy. Neuropharmacology 62:1527-1543. CrossRef Medline

Burns KA, Ayoub AE, Breunig JJ, Adhami F, Weng WL, Colbert MC, Rakic P, Kuan CY (2007) Nestin-CreER mice reveal DNA synthesis by nonapoptotic neurons following cerebral ischemia hypoxia. Cereb Cortex 17: 2585-2592. CrossRef Medline

Chen JF, Eltzschig HK, Fredholm BB (2013) Adenosine receptors as drug targets-what are the challenges? Nat Rev Drug Discov 12:265-286. CrossRef Medline

Costenla AR, Diógenes MJ, Canas PM, Rodrigues RJ, Nogueira C, Maroco J, Agostinho PM, Ribeiro JA, Cunha RA, de Mendonça A (2011) Enhanced role of adenosine $\mathrm{A}(2 \mathrm{~A})$ receptors in the modulation of LTP in the rat hippocampus upon ageing. Eur J Neurosci 34:12-21. CrossRef Medline

Cunha RA, Correia-de-Sá P, Sebastião AM, Ribeiro JA (1996) Preferential activation of excitatory adenosine receptors at rat hippocampal and neuromuscular synapses by adenosine formed from released adenine nucleotides. Br J Pharmacol 119:253-260. CrossRef Medline

Cunha RA, Constantino MD, Ribeiro JA (1997) ZM241385 is an antagonist of the facilitatory responses produced by the $\mathrm{A} 2 \mathrm{~A}$ adenosine receptor agonists CGS21680 and HENECA in the rat hippocampus. Br J Pharmacol 122:1279-1284. CrossRef Medline

Day YJ, Huang L, McDuffie MJ, Rosin DL, Ye H, Chen JF, Schwarzschild MA, Fink JS, Linden J, Okusa MD (2003) Renal protection from ischemia mediated by A2A adenosine receptors on bone marrow-derived cells. J Clin Invest 112:883-891. CrossRef Medline

Dias RB, Rombo DM, Ribeiro JA, Henley JM, Sebastião AM (2013) Adenosine: setting the stage for plasticity. Trends Neurosci 36:248-257. CrossRef Medline

Diógenes MJ, Fernandes CC, Sebastião AM, Ribeiro JA (2004) Activation of adenosine A2A receptor facilitates brain-derived neurotrophic factor modulation of synaptic transmission in hippocampal slices. J Neurosci 24:2905-2913. CrossRef Medline

Diógenes MJ, Costenla AR, Lopes LV, Jerónimo-Santos A, Sousa VC, Fontinha BM, Ribeiro JA, Sebastião AM (2011) Enhancement of LTP in aged rats is dependent on endogenous BDNF. Neuropsychopharmacology 36:1823-1836. CrossRef Medline

Dunwiddie TV, Diao L (1994) Extracellular adenosine concentrations in hippocampal brain slices and the tonic inhibitory modulation of evoked excitatory responses. J Pharmacol Exp Ther 268:537-545. Medline

El Yacoubi M, Ledent C, Parmentier M, Costentin J, Vaugeois JM (2009) Adenosine A2A receptor deficient mice are partially resistant to limbic seizures. Naunyn Schmiedebergs Arch Pharmacol 380:223-232. CrossRef Medline 
Etherington LA, Frenguelli BG (2004) Endogenous adenosine modulates epileptiform activity in rat hippocampus in a receptor subtype-dependent manner. Eur J Neurosci 19:2539-2550. CrossRef Medline

Fedele DE, Koch P, Brüstle O, Scheurer L, Simpson EM, Möhler H, Boison D (2004) Engineering embryonic stem cell derived glia for adenosine delivery. Neurosci Lett 370:160-165. CrossRef Medline

Fedele DE, Li T, Lan JQ, Fredholm BB, Boison D (2006) Adenosine $\mathrm{A}_{1}$ receptors are crucial in keeping an epileptic focus localized. Exp Neurol 200:184-190. CrossRef Medline

Fontinha BM, Diógenes MJ, Ribeiro JA, Sebastião AM (2008) Enhancement of long-term potentiation by brain-derived neurotrophic factor requires adenosine A2A receptor activation by endogenous adenosine. Neuropharmacology 54:924-933. CrossRef Medline

Fredholm BB, Irenius E, Kull B, Schulte G (2001) Comparison of the potency of adenosine as an agonist at human adenosine receptors expressed in Chinese hamster ovary cells. Biochem Pharmacol 61:443448. CrossRef Medline

Giménez-Llort L, Schiffmann SN, Shmidt T, Canela L, Camón L, Wassholm M, Canals M, Terasmaa A, Fernández-Teruel A, Tobeña A, Popova E, Ferré S, Agnati L, Ciruela F, Martínez E, Scheel-Kruger J, Lluis C, Franco R, Fuxe K, Bader M (2007) Working memory deficits in transgenic rats overexpressing human adenosine A2A receptors in the brain. Neurobiol Learn Mem 87:42-56. CrossRef Medline

Gomes CV, Kaster MP, Tomé AR, Agostinho PM, Cunha RA (2011) Adenosine receptors and brain diseases: neuroprotection and neurodegeneration. Biochim Biophys Acta 1808:1380-1399. CrossRef Medline

Gouder N, Fritschy JM, Boison D (2003) Seizure suppression by adenosine $A_{1}$ receptor activation in a mouse model of pharmacoresistant epilepsy. Epilepsia 44:877-885. CrossRef Medline

Gouder N, Scheurer L, Fritschy JM, Boison D (2004) Overexpression of adenosine kinase in epileptic hippocampus contributes to epileptogenesis. J Neurosci 24:692-701. CrossRef Medline

Johansson B, Halldner L, Dunwiddie TV, Masino SA, Poelchen W, GiménezLlort L, Escorihuela RM, Fernández-Teruel A, Wiesenfeld-Hallin Z, Xu XJ, Hårdemark A, Betsholtz C, Herlenius E, Fredholm BB (2001) Hyperalgesia, anxiety, and decreased hypoxic neuroprotection in mice lacking the adenosine A1 receptor. Proc Natl Acad Sci U S A 98:9407-9412. CrossRef Medline

Kochanek PM, Vagni VA, Janesko KL, Washington CB, Crumrine PK, Garman RH, Jenkins LW, Clark RS, Homanics GE, Dixon CE, Schnermann J, Jackson EK (2006) Adenosine A1 receptor knockout mice develop lethal status epilepticus after experimental traumatic brain injury. J Cereb Blood Flow Metab 26:565-575. CrossRef Medline

Leal G, Afonso PM, Salazar IL, Duarte CB (2015) Regulation of hippocampal synaptic plasticity by BDNF. Brain Res 1621:82-101. CrossRef Medline

Li T, Ren G, Lusardi T, Wilz A, Lan JQ, Iwasato T, Itohara S, Simon RP, Boison D (2008) Adenosine kinase is a target for the prediction and prevention of epileptogenesis in mice. J Clin Invest 118:571-582. CrossRef Medline

Lohse MJ, Klotz KN, Schwabe U, Cristalli G, Vittori S, Grifantini M (1988) 2-Chloro-N6-cyclopentyladenosine: a highly selective agonist at Al adenosine receptors. Naunyn Schmiedebergs Arch Pharmacol 337:687-689. Medline

Masino SA, Li T, Theofilas P, Sandau US, Ruskin DN, Fredholm BB, Geiger JD, Aronica E, Boison D (2011) A ketogenic diet suppresses seizures in mice through adenosine A1 receptors. J Clin Invest 121:2679-2683. CrossRef Medline
McGaraughty S, Cowart M, Jarvis MF, Berman RF (2005) Anticonvulsant and antinociceptive actions of novel adenosine kinase inhibitors. Curr Top Med Chem 5:43-58. CrossRef Medline

Papaleo F, Silverman JL, Aney J, Tian Q, Barkan CL, Chadman KK, Crawley JN (2011) Working memory deficits, increased anxiety-like traits, and seizure susceptibility in BDNF overexpressing mice. Learn Mem 18:534544. CrossRef Medline

Pritchard EM, Szybala C, Boison D, Kaplan DL (2010) Silk fibroin encapsulated powder reservoirs for sustained release of adenosine. J Control Release 144:159-167. CrossRef Medline

Rebola N, Coelho JE, Costenla AR, Lopes LV, Parada A, Oliveira CR, Soaresda-Silva P, de Mendonça A, Cunha RA (2003) Decrease of adenosine $A_{1}$ receptor density and of adenosine neuromodulation in the hippocampus of kindled rats. Eur J Neurosci 18:820-828. CrossRef Medline

Schwarzschild MA (2007) Adenosine A2A antagonists as neurotherapeutics: crossing the bridge. Prog Neurobiol 83:261-262. CrossRef Medline

Sebastião AM, Ribeiro JA (1992) Evidence for the presence of excitatory A2 adenosine receptors in the rat hippocampus. Neurosci Lett 138:41-44. CrossRef Medline

Sebastião AM, Ribeiro JA (2009) Adenosine receptors and the central nervous system. Handb Exp Pharmacol 193:471-534. CrossRef Medline

Sebastião AM, Ribeiro JA (2015) Neuromodulation and metamodulation by adenosine: Impact and subtleties upon synaptic plasticity regulation. Brain Res 1621:102-113. CrossRef Medline

Sebastião AM, Stone TW, Ribeiro JA (1990) The inhibitory adenosine receptor at the neuromuscular junction and hippocampus of the rat: antagonism by 1,3,8-substituted xanthines. Br J Pharmacol 101:453-459. CrossRef Medline

Shen HY, Lusardi TA, Williams-Karnesky RL, Lan JQ, Poulsen DJ, Boison D (2011) Adenosine kinase determines the degree of brain injury after ischemic stroke in mice. J Cereb Blood Flow Metab 31:1648-1659. CrossRef Medline

Shen HY, Sun H, Hanthorn MM, Zhi Z, Lan JQ, Poulsen DJ, Wang RK, Boison D (2014) Overexpression of adenosine kinase in cortical astrocytes generates focal neocortical epilepsy in mice. J Neurosurg 120:628 638. CrossRef Medline

Staufner C, Lindner M, Dionisi-Vici C, Freisinger P, Dobbelaere D, Douillard C, Makhseed N, Straub BK, Kahrizi K, Ballhausen D, la Marca G, Kölker S, Haas D, Hoffmann GF, Grünert SC, Blom HJ (2016) Adenosine kinase deficiency: expanding the clinical spectrum and evaluating therapeutic options. J Inherit Metab Dis 39:273-283. CrossRef Medline

Studer FE, Fedele DE, Marowsky A, Schwerdel C, Wernli K, Vogt K, Fritschy JM, Boison D (2006) Shift of adenosine kinase expression from neurons to astrocytes during postnatal development suggests dual functionality of the enzyme. Neuroscience 142:125-137. CrossRef Medline

Tronche F, Kellendonk C, Kretz O, Gass P, Anlag K, Orban PC, Bock R, Klein R, Schütz G (1999) Disruption of the glucocorticoid receptor gene in the nervous system results in reduced anxiety. Nat Genet 23:99-103. CrossRef Medline

Wehner JM, Radcliffe RA (2004) Cued and contextual fear conditioning in mice. Curr Protoc Neurosci Chapter 8:Unit 8.5C. CrossRef Medline

Wieraszko A, Seyfried TN (1989) Increased amount of extracellular ATP in stimulated hippocampal slices of seizure prone mice. Neurosci Lett 106: 287-293. CrossRef Medline

Williams-Karnesky RL, Sandau US, Lusardi TA, Lytle NK, Farrell JM, Pritchard EM, Kaplan DL, Boison D (2013) Epigenetic changes induced by adenosine augmentation therapy prevent epileptogenesis. J Clin Invest 123:3552-3563. CrossRef Medline 